\title{
Factors influencing internal color of cooked meats
}

\author{
Surendranath P. Suman ${ }^{\mathrm{a}, *}$, Mahesh N. Nair ${ }^{\mathrm{a}}$, Poulson Joseph ${ }^{\mathrm{b}}$, Melvin C. Hunt ${ }^{\mathrm{c}}$ \\ ${ }^{a}$ Department of Animal and Food Sciences, University of Kentucky, Lexington, KY \\ 40546, USA \\ ${ }^{\mathrm{b}}$ Kalsec, Kalamazoo, MI 49005, USA \\ ${ }^{c}$ Department of Animal Sciences and Industry, Kansas State University, Manhattan, KS \\ 66506, USA \\ * Corresponding author. Tel: +1-859-257-3248; E-mail: spsuma2@uky.edu
}

Invited Plenary Paper for the $62^{\text {nd }}$ International Congress of Meat Science and Technology, August 14 - 19, 2016, Bangkok, Thailand 


\begin{abstract}
This manuscript overviews the pertinent research on internal color of uncured cooked meats, biochemical processes involved in meat cookery, and fundamental mechanisms governing myoglobin thermal stability. Heat-induced denaturation of myoglobin, responsible for the characteristic dull-brown color of cooked meats, is influenced by a multitude of endogenous (i.e., $\mathrm{pH}$, muscle source, species, redox state) and exogenous (i.e., packaging, ingredients, storage) factors. The interactions between these factors critically influence the internal cooked color and can confuse the consumers, who often perceive cooked color to be a reliable indicator for doneness and safety. While certain phenomena in cooked meat color are cosmetic in nature, others can mislead consumers and result in foodborne illnesses. Research in meat color suggests that processing technologies and cooking practices in industry as well as households influence the internal cooked color. Additionally, the guidelines of many international public health and regulatory authorities recommend using meat thermometers to determine safe cooking endpoint temperature and to ensure product safety.
\end{abstract}

Keywords: internal cooked color; myoglobin denaturation; premature browning; persistent pinking; pink color defect; thermal stability 


\section{Introduction}

Cooking of meat is an ancient practice that has evolved into refined daily cooking techniques (Nam, Jo, \& Lee, 2010) as well as sophisticated modern thermal processing units with multiple process controls (Barbosa-Canovas, Medina-Meza, Candogan, \& Bermudez-Aguirre, 2014). Thermal processing of raw meats is necessary to destroy microorganisms and pathogens, which can be a major source for several foodborne illnesses. For this reason, USDA-FSIS has set specific internal temperature guidelines (USDA, 2013) for cooking muscle foods and recommends using a food thermometer to ensure that the product reaches the required internal temperature to destroy pathogens. Numerous food safety agencies in other countries have provided additional timetemperature combinations that render cooked meats safe for consumption (FDA, 2011).

The cooking process for fresh, uncured meat denatures myoglobin ( $\mathrm{Mb})$ resulting in a dull-brown appearance in the interior of the product. Nonetheless, the interior color can vary based on the degree of doneness achieved. Because consumers associate the change in color of meat from red (raw) to brown (cooked) as a function of thermal treatment, they frequently use internal cooked color of meat products as an indicator of doneness and safety at the point-of-consumption (King \& Whyte, 2006; Holownia, Chinnan, \& Reynolds, 2003a; Mancini \& Hunt, 2005; Suman, Hunt, Nair, \& Rentfrow, 2014). In cooked meat products, dull-brown interiors are considered the hallmark of a well-done product, whereas a pinkish interior color indicates meat cooked to a lower degree of doneness, which can be undercooked and unsafe (King \& Whyte, 2006). Any deviation from the brown appearance in cooked meats can influence consumer perceptions of meat safety. Unfortunately, these visual descriptions of internal color are 
not very accurate or precise. Furthermore, color judgements vary with the observer, the object, and the type and intensity of the lighting, which can lead to inappropriate food safety decisions (AMSA, 2012). From this perspective, internal cooked color in meats is not only a cosmetic concern but also a food safety issue.

The purpose of this manuscript is to review the relevant research on internal color of cooked meats, biochemical processes involved in cooking meat, and fundamental mechanisms governing cooked color phenomena. In addition, the science of cookery methods is covered only by stating the cooking method employed in the reviewed literature.

\section{Biochemistry of cooked meat pigments}

The dull-brown color in cooked meats is due to the heat-induced denaturation of $\mathrm{Mb}$, the water-soluble sarcoplasmic heme protein responsible for the red color of fresh meat. Therefore, the biochemistry of cooked color differs from the color phenomena in fresh meats, where the heme protein is in its native state. Nonetheless, the relationship is strong between the chemistry of $\mathrm{Mb}$ in raw meat and cooked product, and many factors (endogenous and exogenous) affect both (Mancini \& Hunt, 2005; Suman \& Joseph, 2013; Suman \& Joseph, 2014).

Myoglobin, the heme pigment primarily responsible for the red color of fresh meats, denatures upon exposure to heat. Thermal denaturation of $\mathrm{Mb}$ is a process not necessarily happening at a particular point, but rather occurring over a short range of temperature (Bernofsky, Fox, \& Schweigert, 1959; Bowers, Craig, Kropf, \& Tucker, 1987). Lytras, King, and Ledward (2000) studied the kinetics of Mb denaturation in beef 
and lamb burgers cooked to wide range of internal temperatures and observed that $\mathrm{Mb}$ denaturation follows a first order kinetics. Several studies documented increased $\mathrm{Mb}$ denaturation in meats as internal cooking temperatures increased (Bernofsky et al., 1959; Machlik, 1965, Nusimovich, Celmi, \& Pagliaro, 1979; Howe, Gullett, \& Usborne, 1982; Bowers et al., 1987; Trout, 1989; Hague et al., 1994; Lavelle, Hunt, \& Kropf, 1995; Hunt, Sorheim, \& Slinde, 1999; Mancini, Kropf, Hunt, \& Johnson, 2005).

The chemistry of pigments in cooked meat depends on the predominant redox form of $\mathrm{Mb}$ in raw meat before the cooking begins. Therefore, factors governing the chemistry of pigments and color in fresh meat profoundly affect the color of cooked meat as well. Exposure to heat (during cooking/thermal processing) leads to the unfolding (denaturation) of the globin portion of $\mathrm{Mb}$ and results in a concomitant exposure of heme group to the external environment. The exposed heme moiety is more susceptible to oxidation than the heme in its native state. One result of the heat-induced denaturation of globin is that pigments in cooked meats coagulate and become insoluble in water/buffers (Tappel, 1957; Cornforth, 2001). Therefore, reflectance measurements must be used to study cooked meat pigments, while absorbance spectrophotometry is widely used to study fresh meat pigments (Cornforth, 2001; AMSA, 2012).

A variety of pink or brown pigments are formed in cooked meats (Table 1). Globin denaturation in metmyoglobin (MetMb) leads to formation of denatured globin hemichrome (also known as ferrihemochrome), which is responsible for the dull-brown color in cooked meats. Unfolding/denaturation of globin in ferrous $\mathrm{Mb}$ results in formation of pink-red ferrohemochrome (denatured globin hemochrome). Ferrohemochrome is subsequently and readily oxidized to ferrihemochrome. Cooking of 
CO-treated meat leads to heat-induced denaturation of carboxymyoglobin $(\mathrm{COMb})$ and the formation of pink-red pigment, denatured globin $\mathrm{CO}$ hemochrome (Cornforth, Calkins, \& Faustman, 1991). If the heme iron is maintained in the reduced ferrous state, a variety of additional pink hemochromes are possible in cooked meats. After heat-induced denaturation of globin, nicotinamide or other nitrogen-containing ligands can bind with the heme at the coordinate previously occupied by globin. However, the denatured globin may remain associated with heme while nicotinamide or nitrogen-containing ligands associate with the sixth coordinate of heme. Although Maillard reaction products (unrelated to Mb-derived brown pigments) form on the external surfaces of meats during cooking, their contribution is mainly to aroma, not to the internal cooked color (Mottram, 1998). From this standpoint, biochemistry of cooked meat color is primarily dictated by heat-denatured $\mathrm{Mb}$ pigments.

\section{Factors influencing Mb thermal stability}

Both endogenous and exogenous factors affect the redox chemistry of $\mathrm{Mb}$ in fresh meat, and most of them also affect the heme protein's thermal stability and thus, the cooked color. The most important of the influences found in meat processing, which govern $\mathrm{Mb}$ thermal stability are $\mathrm{pH}$, the redox state of $\mathrm{Mb}$, the primary structure (amino acid sequence) of $\mathrm{Mb}$, and the presence of antioxidants and prooxidants. Practically speaking, these four things determine color phenomena in cooked meats.

\subsection{Meat $p H$}


The typical ultimate $\mathrm{pH}$ of post-mortem skeletal muscle in beef, pork, and lamb is 5.5-5.8, whereas post-mortem $\mathrm{pH}$ of avian muscles ranges from 5.7 to 6.0. In contrast, the $\mathrm{pH}$ of live muscle is $\approx 7.2$. As muscle is converted to meat, glycogen breaks down and lactic acid accumulates, and this is reflected as a declined $\mathrm{pH}$. The rate and extent of the pH decline significantly influences Mb functionality and stability (Scopes 1964; Lawrie, 1965). $\mathrm{Mb}$ is more stable at $\mathrm{pH} 7.4$ than at $\mathrm{pH} 5.6$ (Livingston \& Brown, 1981; Gotoh \& Shikama, 1974). Several previous studies (Table 2) examined the relationship between meat $\mathrm{pH}, \mathrm{Mb}$ thermal stability, and cooked color in beef, lamb, pork and turkey. Most studies report that $\mathrm{Mb}$ in meat at a $\mathrm{pH}<5.4$ is less stable to heat, whereas high meat $\mathrm{pH}$ (> 6.0) protects $\mathrm{Mb}$ against heat-induced denaturation and increases the internal redness of cooked meats.

\subsection{Redox state of $M b$}

The thermal stability of $\mathrm{Mb}$ is influenced by the protein's redox state. Machlik (1965) demonstrated that the extent of Mb denaturation depends on the protein's redox state, namely deoxymyoglobin (DeoxyMb), oxymyoglobin (OxyMb), and MetMb. The relative resistance of $\mathrm{Mb}$ forms to heat-induced denaturation was DeoxyMb > OxyMb > MetMb. Further studies (Lavelle et al., 1995; Warren, Hunt, \& Kropf, 1996a, Warren et al., 1996b; Hunt et al., 1999) indicated that both oxidized (MetMb) and oxygenated $(\mathrm{OxyMb})$ pigments in raw ground beef patties are more prone to heat-induced denaturation than their reduced counterpart (DeoxyMb). Investigations using purified $\mathrm{Mb}$ in model systems have also documented that beef MetMb had less resistance to heatinduced denaturation than DeoxyMb and OxyMb (Sepe et al., 2005). Furthermore, Hunt 
et al. (1999) clearly demonstrated the Mb thermal denaturation to be critically influenced by the interactions between redox state, $\mathrm{pH}$, and endpoint temperature. In addition, $\mathrm{COMb}$ was slightly more thermally stable than DeoxyMb, and both were considerably more stable that MetMb and OxyMb (Ballard, 2004). The implication is that at aiven endpoint cooking temperature, meat containing mostly DeoxyMb or $\mathrm{COMb}$ will more likely have red/pink interiors than meat with high proportions of MetMb and $\mathrm{OxyMb}$.

\subsection{Primary structure of $M b$}

The primary structure of $\mathrm{Mb}$ dictates its tertiary (three-dimensional) structure, which in turn influences protein's interactions with ligands and macromolecules, ultimately affecting both fresh and cooked meat color. Redox stability of $\mathrm{Mb}$ is influenced by its primary structure via mechanisms such as autoxidation, heme retention, oxygen affinity, and interactions with biomolecules (Figure 1; Suman \& Joseph, 2013). Thus, Mb primary structure governs the resistance to heat-induced denaturation and influences the color of cooked meats. Comparative studies on thermal stabilities of turkey and beef Mb (Joseph, Suman, Li, Beach, \& Claus, 2010; Joseph et al., 2011) demonstrated that replacement of smaller amino acids in the primary structure with larger ones in turkey $\mathrm{Mb}$ is partially responsible for its greater thermal stability than beef $\mathrm{Mb}$. The relationship between primary structure and thermal stability was also investigated in Mb from several tuna species (Ueki \& Ochiai, 2004). Although the primary structure of $\mathrm{Mb}$ in bigeye tuna is more than $95 \%$ similar to $\mathrm{Mb}$ in yellowfin tuna and bluefin tuna, differential scanning calorimetry revealed that the thermal stability of bigeye tuna $\mathrm{Mb}$ was the lowest among the three species. In a related investigation, bullet tuna $\mathrm{Mb}$ had 
lower thermal stability than $\mathrm{Mb}$ from skipjack, bigeye tuna, bluefin tuna, and yellowfin tuna (Ueki, Chow, \& Ochiai, 2005).

\subsection{Presence of antioxidants and prooxidants}

Many studies have demonstrated that antioxidants (natural or synthetic or an inherent biochemical co-factor) promote formation of reduced cherry-red (OxyMb) or purplish-red (DeoxyMb) pigments in fresh meats (Karre, Lopez, \& Getty, 2013; Shah, Bosco, \& Mir, 2014; Falowo, Fayemi, \& Muchenje, 2014). For instance, incorporating food-grade antioxidants like erythorbate (Phillips, Mancini, Sun, Lynch, \& Faustman, 2001; Sepe et al., 2005, Suman et al., 2005), lactate (Mancini, Suman, Konda, \& Ramanathan, 2009; Suman, Mancini, Ramanathan, \& Konda, 2009), and succinate (Mancini, Ramanathan, Suman, Dady, \& Joseph, 2011) increased the predominance of reduced ferrous $\mathrm{Mb}$ forms, which essentially translates to increased heat stability when cooking beef. Conversely, prooxidant elements (like lipid oxidation and low oxygen partial pressure due to stacking meat) favor formation of ferric $\mathrm{Mb}$, which denatures at a lower temperature than ferrous Mb forms (Machlik, 1965; Warren et al., 1996a, b; Sepe et al., 2005). Thus, packaging systems and numerous ingredients used globally by meat processors may exert positive or negative effects on the final appearance and safety aspects of cooked meats.

\section{Cooked color phenomena in beef}

Consumers generally assess doneness of cooked beef using interior color, which ranges from rare (red interiors) to well-done (brown/gray interiors with no evidence of 
red) visual appearances (King \& Whyte, 2006). Extensive research over the past three decades has characterized the etiology of various cooked color phenomena in wholemuscle beef cuts as well as ground beef. These investigations focused primarily on premature browning and persistent pinking (representing the opposite ends of the spectra) in cooked meats and how processing and production strategies influence color defects in cooked beef.

\subsection{Premature browning in beef}

Premature browning (PMB) is the condition in cooked beef (patties, steaks, or roasts) wherein $\mathrm{Mb}$ denaturation (or browning) occurs at an internal temperature lower than $71^{\circ} \mathrm{C}$ (Hague et al., 1994) and thus falsely conveys that meat has been pasteurized thermally (Bigner-George \& Berry, 2000) when it actually is undercooked.

Enterohemorrhagic E. coli $\mathrm{O} 157: \mathrm{H} 7$ is a foodborne pathogen and a major public health concern. Undercooked beef is one potential vector for human infection (Riley et al., 1983). To ensure destruction of E. coli O157:H7, non-intact beef products, with ground beef of particular concern, should be cooked to an internal temperature of $71^{\circ} \mathrm{C}$, measured using a meat thermometer (USDA, 1997; FAO, 2006; WHO, 2011). E. coli O157:H7 can survive at temperatures $<71^{\circ} \mathrm{C}$, and consumers misled by internal cooked color may become ill (Bigner-George \& Berry, 2000; Boqvist, Fernstrom, Alsanius, \& Lindqvist, 2015). Because analysis of foods associated with outbreaks of E. coli O157:H7 indicates that the infectious dose is less than a hundred cells, PMB is a serious food safety concern (Doyle et al., 1997). 
Numerous cooking times and endpoint temperatures can be employed to achieve thermal destruction of pathogens. For example, USDA (1999) and FDA (2011) list 31 combinations of temperature and time that range from $54.4^{\circ} \mathrm{C}$ for 121 minutes to $71^{\circ} \mathrm{C}$ for 0 second that will kill numerous pathogens. Global meat industry utilizes these combinations for a variety of meat products. Undoubtedly these combinations affect visual color, but their effects are not often researched.

Measuring endpoint temperature of ground product is challenging and requires diligence to be reasonably accurate. Patties, both thick and thin, could have hot and cold spots that could be detected when using thin, fast responding temperature sensors. For research, determining the final "average" endpoint is necessary and requires some practice. Consumers need to be careful about the reliability of their temperature measurements. Nonetheless, even if temperature measurements are done haphazardly, having any temperature measurement is better than none at all, and is much preferred to any judgements of doneness solely based on cooked color. Food establishments that routinely cook patties often use cookery equipment that close and open automatically based on cooking plate temperatures combined with cooking times known to kill pathogens. Thus, food safety is assured without employee action or judgments.

Unfortunately, consumers seldom use meat thermometers for cooking ground beef products. According to an at-home study (Phang \& Bruhn, 2011) on cooking beef burgers, only $4 \%$ of the consumers use a thermometer. In addition, NCBA (2010) reported that only $14 \%$ of the consumers use meat thermometers to ensure doneness, whereas $70 \%$ rely solely on cooked color. The preference of many consumers for undercooked burgers exacerbates this food safety risk (Rossvoll et al., 2013). 
Ground beef cooking juices (Hague et al., 1994) and absence of redness in the meat juice are not reliable indicators for doneness (Nusimovich et al., 1979; Lyon, Berry, Soderberg, \& Clinch, 2000). While changes in the optical (Xia, Weaver, Gerrard, \& Yao, 2008; Pakula \& Stamminger, 2012; Wold, 2016), electric (Brunton, Lyng, Zhang, \& Jacquier, 2006), and structural (Garcia-Segovia, Andres-Bello, \& Martinez-Monzo, 2007) properties of muscle foods can indicate the endpoint cooking temperature, such strategies have limited application in consumer kitchens. Although several studies have proposed that the residual activity of enzymes such as triose phosphate isomerase (Sair, Booren, Berry, \& Smith, 1999), acid phosphatase (Lyon, Davis, Windham, \& Lyon, 2001), and lactate dehydrogenase (Orta-Ramirez et al., 1996; Wang, Abouzied, \& Smith, 1996; Collins, Keeton, \& Smith, 1991; Stalder, Smith, Keeton, \& Smith, 1991, 1997) can indicate the endpoint cooking temperature in ground beef and steaks, such analytical techniques have practical limitations in consumer home cooking.

To engineer strategies to minimize PMB, the etiology and factors contributing to the incidence of PMB in beef need to be clearly characterized. The occurrence of PMB was first noted in beef patties from E-maturity (old) animals (Marksberry, 1990) and thus was initially thought to be related to animal age. However, further studies reported PMB in ground beef from both young and old animals, suggesting that the color defect is not related to animal age (Hague et al., 1994). PMB has been observed at $55^{\circ} \mathrm{C}$, a temperature at which some pink color is normally expected (Lavelle et al., 1995; Warren et al., 1996a, b, Hunt et al., 1999). Approximately 50\% of ground beef retailed in the United States is susceptible to PMB (Killinger, Hunt, Campbell, \& Kropf, 2000). Several studies (Lavelle et al. 1995; Warren et al., 1996a, b; Hunt et al., 1999; Ballard, 2004; 
John et al., 2005; Ryan, Seyfert, Hunt, \& Mancini, 2006; Suman et al., 2011; Mancini et al., 2011) documented that raw ground beef patties containing predominantly MetMb and OxyMb readily undergoes $\mathrm{PMB}$, unlike patties with higher proportions of DeoxyMb and $\mathrm{COMb}$.

Processing technologies and practices typically used by the meat industry to alter fresh beef (raw material) quality can influence the occurrence of PMB in cooked product. More than two-thirds of fresh meat in the United States is retailed in case-ready modified atmosphere packaging (MAP) systems (McMillin, 2008). Several investigations have examined the effect of packaging on PMB in beef products (Table 3). These studies indicated that retailing ground beef and steaks in vacuum packaging increases the proportion of DeoxyMb and in carbon monoxide MAP increases the proportion of $\mathrm{COMb}$, which in turn increases internal cooked redness and minimizes PMB. Conversely, high-oxygen MAP ( $80 \%$ oxygen) enhances the predominance of OxyMb while aerobic over-wrap packaging enhances the predominance MetMb, both of which increase PMB in beef.

Food-grade antioxidants can improve color stability of fresh beef by promoting DeoxyMb and OxyMb formation. Controlling the relative proportion of $\mathrm{Mb}$ redox forms in raw beef using antioxidant technology can also influence internal color of cooked products. Several antioxidants appear to minimize PMB in ground beef as well as steaks (Table 4). For instance, erythorbate (Phillips et al., 2001; Suman et al., 2005; Sepe et al., 2005), ascorbate (Sepe et al., 2005), chitosan (Suman et al., 2011), and succinate (Mancini et al., 2011; Ramanathan, Mancini, Dady, \& Van Buiten, 2013) minimize PMB and increase internal redness in cooked beef patties. Similarly, injecting a solution 
containing lactate enhances internal cooked redness in whole-muscle beef cuts (Papadopoulos, Miller, Ringer, \& Cross, 1991; Suman et al., 2009; Kim, Keeton, Hunt, \& Savell, 2010). On the other hand, antioxidants like vitamin E (Lavelle et al., 1995), lactate (Mancini et al., 2010), and ascorbyl palmitate (Sepe et al., 2005) did not prevent PMB in ground beef. Interestingly, some of this same research indicated that the effects of antioxidants to minimize PMB depend on the type of packaging used for display, with high-oxygen MAP nullifying the effects of antioxidants like erythorbate (Suman et al., 2005), lactate (Suman et al., 2009), and chitosan (Suman et al., 2011). In contrast, the ability of succinate to prevent PMB was not affected by packaging system (Mancini et al., 2011), and this ingredient may well be used to minimize PMB in beef retailed in high-oxygen MAP systems.

Previous investigations documented the role of both exogenous and endogenous factors governing PMB in beef. Many practices commonly found in the beef industry, retail stores, hospitality services, and household kitchens influence PMB (Table 5). For instance, muscle source influences internal cooked color (Suman et al., 2004; Seyfert et al., 2004a; Suman et al., 2009). Ground beef (Suman et al., 2004) and steaks (Suman et al., 2009) from psoas major muscle demonstrated more internal cooked redness than longissimus lumborum, possibly because beef psoas is reported to have a higher $\mathrm{pH}$ than beef longissimus (Suman et al., 2004; Seyfert et al., 2006; Joseph, Suman, Rentfrow, Li, \& Beach, 2012) which may also help minimize thermal denaturation of Mb. A wide variety of cookery methods and equipment are used to prepare beef products in household kitchens as well as hospitality services (AMSA, 2015). Research also shows that the method of cooking (fast vs. slow; Ryan et al., 2006) and the choice of cooking 
utensil (Yancey, Wharton, \& Apple, 2011; Bowers, Dikeman, Murray, \& Stroda, 2012) affect the internal cooked color of beef. In addition, fat content (Liu \& Berry, 1996; Berry \& Bigner-George, 2000), thawing frozen meat (Bigner-George \& Berry, 2000; Suman et al., 2005), and bulk storage (Suman et al., 2005) have a profound effect on the internal cooked color of the end product (Table 5).

Results from the aforementioned studies indicated existence of critical interactions between $\mathrm{pH}, \mathrm{Mb}$ redox forms, and endpoint temperature influencing the incidence of PMB. Moreover, many combinations of raw material quality, processing protocols, oxygen partial pressures (low or high) encountered with packaging and storage, non-meat ingredients, and final product handling and heating by consumers before and during cooking can contribute to foodborne illness from undercooked ground beef products and non-intact whole-muscle beef cuts.

\subsection{Persistent pinking in beef}

Persistent pinking is a defect in cooked beef characterized by an abnormal pink appearance in fully-cooked product, which is undesirable because the consumers anticipate a dull-brown color. Beef with persistent pinking is often considered undercooked and unsafe, although the final endpoint temperature indicates a well-done product. Therefore, persistent pinking in beef is a cosmetic issue on cooked meat quality rather than a food safety problem; beyond the objectionable pink color, harm to consumers by persistent pinking is very unlikely.

Although pinking in beef can be traced to a number of causes (AMSA, 2012), the most prominent one is a meat $\mathrm{pH}$ higher than normal. Table 2 summarizes several studies 
that document a strong relationship between internal cooked color, $\mathrm{Mb}$ redox forms, $\mathrm{pH}$, and $\mathrm{Mb}$ denaturation. $\mathrm{A} \mathrm{pH}$ higher than normal value (> 5.7) protects $\mathrm{Mb}$ from heatinduced denaturation (Trout, 1989; Moiseev \& Cornforth, 1999). Therefore, high-pH beef products remain pink in the interior even after cooking (Cornforth et al., 1991; Berry \& Bigner-George, 1999; Van Laack, Berry, \& Solomon, 1997; Swan \& Boles, 2002). The incidence of high $\mathrm{pH}$ is widely observed in dark-cutting beef (Fabiansson, Erichsen, Reutersward, \& Malmfors, 1984), and beef cattle with Bos indicus influence are predisposed to dark cutting (Shackelford, Koohmaraie, Wheeler, Cundiff, \& Dikeman, 1994; Voisinet, Grandin, O'Connor, Tatum, \& Deesing, 1997; Page, Wulf, \& Schwotzer, 2001).

To add to the confusion, incomplete combustion products like $\mathrm{CO}$, nitric oxide, nitrogen dioxide from oven gases or wood-fired barbeques, and elevated levels of nitrate/nitrite in water contribute to pinking in cooked meats (Cornforth et al., 1991; 1998). Beef harvested from grass-fed cattle and stressed animals may also have a $\mathrm{pH}>$ 5.9, and the combination of high-pH beef and combustion products during cooking can exacerbate pinking. The $\mathrm{pH}$ of different muscles in a beef carcass may vary from 5.6 to $\leq$ 6.0 (McKenna et al., 2005) and cooked color can vary by the muscle (Suman et al., 2009; Seyfert et al., 2004a); thus, muscle source can possibly contribute to the incidence of persistent pinking.

Moiseev \& Cornforth (1999) reported that adding lactic acid and calcium peroxide increased $\mathrm{Mb}$ denaturation and browning in patties. Furthermore, in model systems, lactate increased heat-induced denaturation of beef Mb (Figure 2; Nair et al., 2014). Indeed, several studies have reported the usefulness of lactate enhancement to 
minimize pinking in dark-cutting beef and observed that the interiors of cooked lactateenhanced dark-cutting steaks were less pink than the interiors of controls (Sawyer, Apple, \& Johnson, 2008; Sawyer, Apple, Johnson, Baublits, \& Yancey, 2009; Apple, Sawyer, Meullenet, Yancey, \& Wharton, 2011). These findings suggested lactate-enhancement as a practical strategy to minimize persistent pinking in dark-cutting beef.

\section{Cooked color phenomena in pork}

Although cooked color in beef has seen extensive research, cooked pork color has not received the same attention. Different organizations suggest different minimum endpoint temperatures $\left(71^{\circ} \mathrm{C}\right.$ as recommended by the USDA; $68^{\circ} \mathrm{C}$ as recommended by the NPPC, 2000) for cooking pork to ensure destruction of the heat-sensitive parasite Trichinella spiralis that causes trichinosis; so it is little wonder consumers are confused about cooking pork. Not surprisingly, consumers tend to overcook pork (Hunt \& Zenger, 2002) because of concerns about Trichinella spiralis (Carlin et al., 1969). Pork consumers prefer juicy products (Moeller et al., 2010), perceive darker fresh chops to be juicy when cooked (Norman et al., 2003), and consider pink interiors as unsafe (Hunt \& Zenger, 2002).

The redox biochemistry of beef and pork $\mathrm{Mb}$, as reflected in species-specific fresh meat color stability, differs inherently (Suman, Mancini, \& Faustman, 2006; Suman, Faustman, Stamer, \& Liebler, 2007; Yin et al., 2011), as does the thermal stability. Pork $\mathrm{Mb}$ is more resistant to heat-induced denaturation than beef $\mathrm{Mb}$ in model systems (Nair et al., 2014). This species-specific difference is in turn reflected in certain aspects of cooked color. For instance, thawing decreases internal redness in cooked ground beef (Van Laack 
et al., 1996a; Berry \& Bigner-George, 2000; Bigner-George \& Berry, 2000; Suman et al., 2005), but the reverse occurs in pork patties (Lien et al., 2002b). Tables 6 and 7 summarize the impact of endogenous and exogenous factors on the cooked color of various pork products like chops, ground pork, and uncured ground sausages. These studies indicate that cooked pork color is influenced by such intrinsic factors as the quality of the fresh pork (Lewis, Yakes, Noland, \& Brown, 1987; Lien et al., 2002a, b), the sex of the pig (Brown, Warriss, Nute, Edwards, \& Knowles, 1998), and muscle fiber characteristics (Nam et al., 2009). In addition, storage (Lien et al., 2002b), packaging system (Wicklund et al., 2006; De Santos, Rojas, Lockhorn, \& Brewer, 2007), and cooking method (Vittadini, Rinaldi, Chiavaro, Barbanti, \& Massini, 2005; Chiavaro, Rinaldi, Vittadini, \& Barbanti, 2009; Dai et al., 2009) can influence internal cooked color of pork products. Adding salt (Wettasinghe \& Shahidi, 1997) had no effect on cooked pork color, but lactate (Wang \& Brewer, 1999) decreased internal redness.

Natural antioxidants like spices and plant extracts have been used in muscle foods rich in polyunsaturated fatty acids to minimize oxidative changes (Karre et al., 2013; Shah et al., 2014; Falowo et al., 2014). Plant-derived antioxidants can have positive impact on fresh meat color due to the interrelationship between lipid peroxidation and Mb stability (Baron \& Andersen, 2002; Faustman, Sun, Mancini, \& Suman, 2010; Joseph, Nair, \& Suman, 2015). However, studies show only inconsistent results in the effects of natural antioxidants on cooked pork color. While several investigations (Fernandez-Lopez et al., 2003; Carpenter, O'Grady, O'Callaghan, O'Brien, \& Kerry, 2007; Kong, Zhang, \& Xiong, 2010; Ryu, Shim, \& Shin, 2014) reported an increase in redness of cooked patties/sausages containing plant-derived extracts, other studies (Rojas 
\& Brewer et al., 2007; Sasse, Colindres, \& Brewer, 2008) documented no effect among several natural ingredients..

\section{Cooked color phenomena in poultry}

Cooked color in poultry is starkly different from that of red meats (King \& Whyte, 2006; Holownia et al., 2003a). This is in part due to inherent differences in the concentration and biochemistry of Mb between the avian and mammalian species (Suman \& Joseph, 2013). On the applied aspect, it may also be due to the fact that poultry products are cooked to a greater internal temperature than beef and pork; USDA (2013) recommends all poultry products (breasts, whole bird, legs, thighs, and wings, ground poultry, and stuffing) be cooked to an internal temperature of $74^{\circ} \mathrm{C}$.

The major problem widely reported and studied in poultry is the pink color defect (PCD). The PCD is the appearance of uncooked pink color in fully cooked, uncured poultry products (Holownia et al., 2003a, b). This pink color may be visible throughout a cross-section or may only exist as a pink ring or region near the bone. Although documented both in turkey and chicken, PCD is a quality concern mainly in the turkey industry affecting 1-2\% of birds harvested annually (Nalivka, 2003). While PCD products are microbiologically safe, consumers reject them, attributing the pink appearance as an indicator of an undercooked product. This ultimately leads to revenue loss.

Previous research on PCD has examined the influence of pre-slaughter (genetics, feeding, stunning, and stress) and post-slaughter (presence of nitrites, use of gas-fired ovens, irradiation, and non-meat ingredients) elements in poultry production and 
processing. Most of these investigations observed that PCD is primarily due to the interactions of $\mathrm{Mb}$ with ligands and the protein's resistance to heat-induced denaturation. Cornforth, Vahabzadeh, Carpenter, and Bartholomew (1986) characterized heme pigments responsible for $\mathrm{PCD}$, concluding that $\mathrm{PCD}$ was related to redox potential within the meat. Reducing environments in meat increased the incidence of PCD, whereas an oxidizing milieu inhibited PCD, in this case in turkey. Furthermore, investigations (Cornforth et al., 1986; Claus, Shaw, \& Marcy, 1994) revealed that cooked turkey with added nicotinamide had reflectance spectra similar to PCD samples, suggesting nicotinamide, a biological antioxidant (Brown \& Snyder, 1969), potentially contributed to PCD.

Trout (1989) investigated the relationship between percent $\mathrm{Mb}$ denaturation and cooked color in beef, pork, and turkey to seek an explanation for PCD. Turkey meat had less $\mathrm{Mb}$ denaturation than beef and pork at $\mathrm{pH} 5.6$ (typical $\mathrm{pH}$ of red meat), 6.0 (typical $\mathrm{pH}$ of turkey), and 6.5. These results suggested that turkey $\mathrm{Mb}$ is more resistant to heatinduced denaturation than red meat $\mathrm{Mb}$. In addition, this indicates that heat resistance of turkey $\mathrm{Mb}$ and the resulting incomplete denaturation could be a major reason for PCD. The results of further investigations (Girard, Vanderstoep, \& Richards, 1989; 1990) agreed with this.

Several researchers have evaluated the ways in which $\mathrm{Mb}$ interacts with combustion products, such as $\mathrm{CO}$, nitric oxide, and nitrogen dioxide, to examine the molecular mechanisms leading to PCD. Although nitric oxide and $\mathrm{CO}$ are well-known as influencers on meat color through their chemical reactions with $\mathrm{Mb}$, their concentrations in gas-fired ovens are too low to cause PCD. Nitrogen dioxide, on the other hand, was the 
most potent component in inducing PCD (Cornforth et al., 1998). However, other studies (Nam \& Ahn, 2002a, b) have reported that CO generated during irradiation was a possible pinking ligand and that $\mathrm{COMb}$, which has a greater denaturation temperature than the other redox forms, was the pigment responsible for PCD in irradiated turkey.

Comparative studies (Joseph et al., 2010; 2011) on the thermal stability and biochemistry of turkey and beef $\mathrm{Mb}$ have shown that the molecular mass of turkey $\mathrm{Mb}$ is $350 \mathrm{Da}$ greater than beef Mb (Figure 3; Joseph et al., 2010). Joseph et al. (2011) reported that several amino acids in turkey $\mathrm{Mb}$ are larger than those in beef $\mathrm{Mb}$, which may contribute to the increased thermal stability of turkey $\mathrm{Mb}$. The results also showed a greater thermal stability inherent in turkey $\mathrm{Mb}$, in contrast to beef $\mathrm{Mb}$, and indicated that this is a major contributor to PCD (Joseph et al., 2010). Moreover, because turkey and chicken $\mathrm{Mb}$ share $100 \%$ similarity in their primary structure (Joseph et al., 2011), the aforementioned finding explains why PCD is observed primarily in these two poultry species (Holownia et al., 2003a).

Several investigations revealed the effects of non-meat ingredients in mitigating PCD in poultry products. These studies indicated that milk-derived ingredients (Table 8) such as non-fat dry milk (Dobson \& Cornforth, 1992; Schwarz et al., 1997; Schwarz et al., 1999; Slesinski et al., 2000a), whey protein concentrate (Slesinski et al., 2000a; Sammel \& Claus, 2003b), sodium caseinate (Slesinski et al., 2000a), and milk protein concentrate (Slesinski et al., 2000a) minimize PCD in poultry products. In addition, PCD can be decreased using common food-grade ingredients (Table 9) like citrate (Sammel \& Claus, 2003a; Sammel, Claus, Greaser, \& Richards, 2006; Kieffer, Claus, \& Wang, 2000), calcium chloride (Sammel \& Claus, 2007; Sammel et al., 2007), tricalcium 
phosphate (Sammel \& Claus, 2007), sodium tripolyphosphate (Young \& Lyon, 1997), EDTA (Schwarz et al., 1999; Slesinski et al., 2000b), and annatto (Sammel et al., 2007).

Sammel et al. (2006) attempted to explain the mechanism through which sodium citrate minimizes pinking, and reported that this ingredient requires oxygen and possibly participates in oxidative processes to inhibit pinking in cooked ground turkey. Nonetheless, the exact mechanisms through which the aforementioned ingredients (Tables 8 and 9) minimize pinking in cooked poultry are not yet clearly understood. Notably, the effects of some ingredients were product-dependent. For instance, sodium citrate (Sammel \& Claus, 2003a), citric acid (Sammel \& Claus, 2003a), calcium chloride, (Sammel \& Claus, 2007), and tricalcium phosphate (Sammel \& Claus, 2007) were effective in minimizing PCD in ground turkey but had no effect on intact turkey muscle. The observed variations between the ground meat and whole muscle turkey products suggest possible interactions of the ingredients with muscle structural integrity and homogeneity of the product.

\section{Conclusions}

Although meat is dead skeletal muscle tissue, it is not inert. The complex interactions between $\mathrm{Mb}$ and biomolecules in muscle food matrix critically influence internal color of cooked meats. The major observations from the extensive research undertaken in cooked meat color are summarized below.

- Mb thermal stability is species-specific and governed by primary structure.

- Heat-induced denaturation of $\mathrm{Mb}$ is influenced by meat $\mathrm{pH}$ and the protein's redox state before cooking. 
- Internal cooked color of meat is profoundly influenced by packaging system, nonmeat ingredients, storage, muscle source, and species.

- Color of cooked meat and meat juice is not a reliable indicator of pathogen destruction.

- While some color defects in cooked meats are cosmetic quality concerns, others can lead to food safety and public health concerns

- Numerous regulatory and public health agencies have studied and validated the interactions between cooking time and endpoint temperature that are fundamental to ensuring safety of cooked meat

- Using a meat thermometer is highly recommended to ensure product interiors have reached temperatures sufficient to destroy foodborne pathogens

\section{Acknowledgements}

This is publication number 16-07-015 of the Kentucky Agricultural Experiment Station and is published with the approval of the director. This work is supported by the National Institute of Food and Agriculture, U.S. Department of Agriculture, HatchMultistate Project 1008755. 


\section{References}

AMSA. (2012). Meat color measurement guidelines. American Meat Science Association, Champaign, IL, USA.

AMSA. (2015). Research guidelines for cookery, sensory evaluation, and instrumental tenderness measurements of meat. American Meat Science Association, Champaign, IL, USA.

Apple, J.K., Sawyer, J.T., Meullenet, J. -F., Yancey, J.W.S., \& Wharton, M.D. (2011). Lactic acid enhancement can improve the fresh and cooked color of dark-cutting beef. Journal of Animal Science, 89, 4207-4220.

Ballard, C. (2004). Thermal denaturation of carboxymyoglobin and the affect of carbon monoxide and injection enhancement on display and cooked color. MS Thesis. Kansas State Univ., Manhattan.

Barbosa-Canovas, G.V., Medina-Meza, I., Candogan, K., \& Bermudez-Aguirre, D. (2014). Advanced retorting, microwave assisted thermal sterilization (MATS), and pressure assisted thermal sterilization (PATS) to process meat products. Meat Science, 98, 420-434.

Baron, C.P., \& Andersen, H.J. (2002). Myoglobin-induced lipid oxidation. A review. Journal of Agricultural and Food Chemistry, 50, 3887-3897.

Bernofsky, C., Fox, J.B, \& Schweigert, B.S. (1959). Biochemistry of myoglobin. VII. The effect of cooking on myoglobin in beef muscle. Journal of Food Science, 24, 339-343.

Berry, B.W. (1998a). Color of cooked beef patties as influenced by formulation and final internal temperature. Food Research International, 30, 473-478.

Berry, B.W. (1998b). Cooked color in high $\mathrm{pH}$ beef patties as related to fat content and cooking from the frozen or thawed state. Journal of Food Science, 63, 797-800.

Berry, B.W., \& Bigner-George, M.E. (1999). Properties of beef patties cooked to elevated internal temperatures as a means of reducing pink color. Journal of Muscle Foods, 10, 215-230.

Berry, B.W., \& Bigner-George, M.E. (2000). Factors affecting color properties of beef patties cooked on an outdoor gas grill. Journal of Muscle Foods, 11, 213-226.

Bigner-George, M.E., \& Berry, B.W. (2000). Thawing prior to cooking affects sensory, shear force, and cooking properties of beef patties. Journal of Food Science, 65, 2-8.

Boqvist, S., Fernstrom, L.-L., Alsanius, B.W., \& Lindqvist, R. (2015). Escherichia coli O157: $\mathrm{H} 7$ reduction in hamburgers with regard to premature browning of minced beef, colour score and method for determining doneness. International Journal of Food Microbiology, 215, 109-116.

Bowers, J.A., Craig, J.A., Kropf, D.H., \& Tucker, T.J. (1987). Flavor, color, and other characteristics of beef longissimus muscle heated to seven internal temperatures between $55^{\circ}$ and $85^{\circ}$ C. Journal of Food Science, 52, 533-536.

Bowers, L.J., Dikeman, M.E., Murray, L., \& Stroda, S.L. (2012). Cooked yields, color, tenderness, and sensory traits of beef roasts cooked in an oven with steam generation versus a commercial convection oven to different endpoint temperatures. Meat Science, 92, 97-106. 
Brewer, M.S., \& Novakofski, J. (1999). Cooking rate, $\mathrm{pH}$ and final endpoint temperature effects on color and cook loss of a lean ground beef model system. Meat Science, $52,443-451$.

Brown, S.N, Warriss, P.D., Nute, G.R., Edwards, J.E., \& Knowles, T.G. (1998). Meat quality in pigs subjected to minimal preslaughter stress. Meat Science, 49, 257265.

Brown, W.D., \& Snyder, H.E. (1969). Nonenzymatic reduction and oxidation of myoglobin and hemoglobin by nicotinamide adenine dinucleotides and flavins. Journal of Biological Chemistry, 244, 6702-6706.

Brunton, N.P., Lyng, J.G., Zhang, L., \& Jacquier, J.C. (2006). The use of dielectric properties and other physical analyses for assessing protein denaturation in beef biceps femoris muscle during cooking from $5^{\circ}$ to $85^{\circ} \mathrm{C}$. Meat Science, 72, 236244.

Carlin, A.F., Mott, C., Cash, D., \& Zimmermann, W. (1969). Destruction of trichina larvae in cooked pork roasts. Journal of Food Science, 34, 210-212.

Carpenter, R., O'Grady, M.N., O'Callaghan, Y.C., O'Brien, N.M., \& Kerry, J.P. (2007). Evaluation of the antioxidant potential of grape seed and bearberry extracts in raw and cooked pork. Meat Science, 76, 604-610.

Chiavaro, E., Rinaldi, M., Vittadini, E., \& Barbanti, D. (2009). Cooking of pork Longissimus dorsi at different temperature and relative humidity values: Effects on selected physico-chemical properties. Journal of Food Engineering, 93, 158165.

Claus, J.R., Shaw, D.E., \& Marcy, J.A. (1994). Pink color development in turkey meat as affected by nicotinamide, cooking temperature, chilling rate, and storage time. Journal of Food Science, 59, 1283-1285.

Collins, S.S., Keeton, J.T., \& Smith, S.B. (1991). Lactate dehydrogenase activity in bovine muscle as a potential heating endpoint indicator. Journal of Agricultural and Food Chemistry, 39, 1291-1293.

Cornforth, D. (2001). Spectrophotometric and reflectance measurements of pigments of cooked and cured meats. Current Protocols in Food Analytical Chemistry, F3.2.1F3.2.8.

Cornforth, D., Calkins, C.R., \& Faustman, C. (1991). Methods for identification and prevention of pink color in cooked meat. In Proc. Reciprocal Meat Conf., pp. 5358, American Meat Science Association, Savoy, IL.

Cornforth, D.P., Rabovitser, J.K., Ahuja, S., Wagner, J.C., Hanson, R., Cummings, B., \& Chudnovsky, Y. (1998). Carbon monoxide, nitric oxide, and nitrogen dioxide levels in gas ovens related to surface pinking of cooked beef and turkey. Journal of Agricultural and Food Chemistry, 46, 255-261.

Cornforth, D.P., Vahabzadeh, F., Carpenter, C.E., \& Bartholomew, D.T. (1986). Role of reduced hemochromes in pink color defect of cooked turkey rolls. Journal of Food Science, 51, 1132-1135.

Dai, Y., Miao, J., Yuan, S.-Z., Liu, Y., Li, X.-M., \& Dai, R.-T. (2013). Colour and sarcoplasmic protein evaluation of pork following water bath and ohmic cooking. Meat Science, 93, 898-905. 
De Santos, F., Rojas, M., Lockhorn, G., \& Brewer, M.S. (2007). Effect of carbon monoxide in modified atmosphere packaging, storage time and endpoint cooking temperature on the internal color of enhanced pork. Meat Science, 77, 520-528.

Dobson, B.N., \& Cornforth, D. P. (1992). Nonfat dry milk inhibits pink discoloration in turkey rolls. Poultry Science, 71, 1943-1946.

Doyle, M.P., Zhao, T., Meng, J., and Zhao, S. (1997). Escherichia coli O157:H7. In "Food Microbiology: Fundamentals and Frontiers," ed. M.P. Doyle, L.R. Beuchat, and T.J. Montville, pp. 171-191. ASM Press, Washington, D.C

Fabiansson, S., Erichsen, I., Reuterswärd, A.L., \& Malmfors, G. (1984). The incidence of dark cutting beef in Sweden. Meat Science, 10, 21-33.

Falowo, A. B., Fayemi, P. O., \& Muchenje, V. (2014). Natural antioxidants against lipidprotein oxidative deterioration in meat and meat products: A review. Food Research International, 64, 171-181.

FAO (2006). Case study: Escherichia coli O157:H7 in fresh raw ground beef. http://www.fao.org/fileadmin/templates/agns/pdf/jemra/Ecoli.pdf

Faustman, C., Sun, Q., Mancini, R., \& Suman, S. P. (2010). Myoglobin and lipid oxidation interactions: Mechanistic bases and control. Meat Science, 86, 86-94.

FDA (Food and Drug Administration). (2011) FDA Food Code 2009: Chapter 3 - Food, Section 3-4 Destruction of Organisms of Public Health Concern. 401.11 Raw Animal Products.

Fernández-López, J., Sevilla, L., Sayas-Barberá, E., Navarro, C., Marin, F., \& PérezAlvarez, J.A. (2003). Evaluation of the antioxidant potential of hyssop (Hyssopus officinalis L.) and rosemary (Rosmarinus officinalis L.) extracts in cooked pork meat. Journal of Food Science, 68, 660-664.

García-Segovia, P., Andrés-Bello, A., \& Martínez-Monzó, J. (2007). Effect of cooking method on mechanical properties, color and structure of beef muscle (M. pectoralis). Journal of Food Engineering, 80, 813-821.

Ghorpade, V.M., \& Cornforth, D. P. (1993). Spectra of pigments responsible for pink color in pork roasts cooked to 65 or 82 C. Journal of Food Science, 58, 51-52.

Girard, B., Vanderstoep, J., \& Richards, J.F. (1989). Residual pinkness in cooked turkey and pork muscle. Canadian Institute of Food Science and Technology Journal, 22(4), 372-377.

Girard, B., Vanderstoep, J., \& Richards, J.F. (1990). Characterization of the residual pink color in cooked turkey breast and pork loin. Journal of Food Science, 55, 12491254.

Gotoh, T., \& Shikama, K. (1974). Autoxidation of native oxymyoglobin from bovine heart muscle. Archives of Biochemistry and Biophysics, 163, 476-481.

Grobbel, J.P., Dikeman, M.E., Hunt, M.C., \& Milliken, G.A. (2008). Effects of packaging atmospheres on beef instrumental tenderness, fresh color stability, and internal cooked color. Journal of Animal Science, 86, 1191-1199.

Hague, M.A., Warren, K.E., Hunt, M.C., Kropf, D.H., Kastner, C.L., Stroda, S.L., \& Johnson, D.E. (1994). Endpoint temperature, internal cooked color, and expressible juice color relationships in ground beef patties. Journal of Food Science, 59, 465-470. 
Hamouz, F.L., Eilert, S.J., Mandigo, R.W., \& Calkins, C.R. (1996). Impact of foodservice equipment and temperatures on quality characteristics of boneless pork chops. Journal of Food Quality, 19, 443-455.

Heymann, H., Hedrick, H.B., Karrasch, M.A., Eggeman, M.K., \& Ellersieck, M.R. (1990). Sensory and chemical characteristics of fresh pork roasts cooked to different endpoint temperatures. Journal of Food Science, 55, 613-617.

Holownia, K., Chinnan, M.S., \& Reynolds, A.E. (2003a). Pink color defect in poultry white meat as affected by endogenous conditions. Journal of Food Science, 68, $742-747$.

Holownia, K., Chinnan, M.S., Reynolds, A.E., \& Koehler, P.E. (2003b). Evaluation of induced color changes in chicken breast meat during simulation of pink color defect. Poultry Science, 82, 1049-1059.

Howe, J.L., Gullett, E.A., \& Usborne, W.R. (1982). Development of pink color in cooked pork. Canadian Institute of Food Science and Technology Journal, 15, 19-23.

http://www.fda.gov/Food/GuidanceRegulation/RetailFoodProtection/FoodCode/u cm186451.htm

Hunt, M.C., \& Zenger, B. (2002). Cooked color in pork. FACTS National Pork Board, 1637, 1-4.

Hunt, M.C., Sorheim, O., \& Slinde, E. (1999). Color and heat denaturation of myoglobin forms in ground beef. Journal of Food Science, 64, 847-851.

John, L., Cornforth, D., Carpenter, C.E., Sorheim, O., Pettee, B.C., \& Whittier, D.R. (2004). Comparison of color and thiobarbituric acid values of cooked hamburger patties after storage of fresh beef chubs in modified atmospheres. Journal of Food Science, 69, C608-C614.

John, L., Cornforth, D., Carpenter, C.E., Sorheim, O., Pettee, B.C., \& Whittier, D.R. (2005). Color and thiobarbituric acid values of cooked top sirloin steaks packaged in modified atmospheres of $80 \%$ oxygen, or $0.4 \%$ carbon monoxide, or vacuum. Meat Science, 69, 441-449.

Joseph, P., Nair, M.N., \& Suman, S.P. (2015). Application of proteomics to characterize and improve color and oxidative stability of muscle foods. Food Research International, 76, 938-945.

Joseph, P., Suman, S.P., Li, S., Beach, C.M, \& Claus, J.R. (2010). Mass spectrometric characterization and thermostability of turkey myoglobin. LWT-Food Science and Technology, 43, 273-278.

Joseph, P., Suman, S.P., Li, S., Claus, J.R., Fontaine, M., \& Steinke, L. (2011). Primary structure of turkey myoglobin. Food Chemistry, 129, 175-178.

Joseph, P., Suman, S.P., Rentfrow, G., Li, S., \& Beach, C.M. (2012). Proteomics of muscle-specific beef color stability. Journal of Agricultural and Food Chemistry, 60, 3196-3203.

Karre, L., Lopez, K., \& Getty, K.J.K. (2013). Natural antioxidants in meat and poultry products. Meat Science, 94, 220-227.

Kieffer, K.J., Claus, J.R., \& Wang, H. (2000). Inhibition of pink color development in cooked, cncured ground turkey by the addition of citric acid. Journal of Muscle Foods, 11, 235-243. 
Killinger, K.M., Hunt, M.C., Campbell, R.E., \& Kropf, D.H. (2000). Factors affecting premature browning during cooking of store-purchased ground beef. Journal of Food Science, 65, 585-588.

Kim, J.-H., Hong, G.-E., Lim, K.-W., Park, W., \& Lee, C.-H. (2015). Influence of citric acid on the pink color and characteristics of sous vide processed chicken breasts during chill storage. Korean Journal for Food Science of Animal Resources, 35, 585.

Kim, Y.H., Keeton, J.T., Hunt, M.C., \& Savell, J.W. (2010). Effects of L- or D-lactateenhancement on the internal cooked colour development and biochemical characteristics of beef steaks in high-oxygen modified atmosphere. Food Chemistry, 119, 918-922.

King, N.J., \& Whyte, R. (2006). Does it look cooked? A review of factors that influence cooked meat color. Journal of Food Science, 71, R31-R40.

Kong, B., Zhang, H., \& Xiong, Y.L. (2010). Antioxidant activity of spice extracts in a liposome system and in cooked pork patties and the possible mode of action. Meat Science, 85, 772-778.

Lagerstedt, A., Ahnström, M.L., \& Lundström, K. (2011). Vacuum skin pack of beef-A consumer friendly alternative. Meat Science, 88, 391-396.

Lavelle, C.L., Hunt, M.C., \& Kropf, D.H. (1995). Display life and internal cooked color of ground beef from vitamin E-supplemented steers. Journal of Food Science, 60, $1175-1178$.

Lawrie, R.A. (1965) Metabolic stresses which affect muscle. In: The Physiology and biochemistry of muscle as a food. Eds: E.J. Briskey, R.G. Cassens and J.C. Trautman. The University of Wisconsin Press, Madison WI. Page 137-164.

Lewis, P.K., Yakes, L.Y., Noland, P.R., \& Brown, C.J. (1987). The effect of DFD classification and internal cooking temperature on certain pork muscle characteristics. Meat Science, 21, 137-144.

Lien, R., Hunt, M.C., Anderson, S., Kropf, D.H., Loughin, T.M., Dikeman, M.E., \& Velazco, J. (2002a). Effects of endpoint temperature on the internal color of pork loin chops of different quality. Journal of Food Science, 67, 1007-1010.

Lien, R., Hunt, M.C., Anderson, S., Kropf, D.H., Loughin, T.M., Dikeman, M.E., \& Velazco, J. (2002b). Effects of endpoint temperature on the internal color of pork patties of different myoglobin form, initial cooking state, and quality. Journal of Food Science, 67, 1011-1015.

Liu, M.N., \& Berry, B.W. (1996). Variability in color, cooking times, and internal temperature of beef patties under controlled cooking conditions. Journal of Food Protection, 59, 969-975.

Livingston, D.J., \& Brown, W.D. (1981). The chemistry of myoglobin and its reactions [Meat pigments, food quality indices]. Food Technology, 35,238-252.

Lyon, B.G., Berry, B.W., Soderberg, D., \& Clinch, N. (2000). Visual color and doneness indicators and the incidence of premature brown color in beef patties cooked to four end point temperatures. Journal of Food Protection, 63, 1389-1398.

Lyon, B.G., Davis, C.E., Windham, W.R., \& Lyon, C.E. (2001). Acid phosphatase activity and color changes in consumer-style griddle-cooked ground beef patties. Journal of Food Protection, 64, 1199-1205. 
Lytras, G.N., Geileskey, A., King, R.D., \& Ledward, D.A. (1999). Effect of muscle type, salt and $\mathrm{pH}$ on cooked meat haemoprotein formation in lamb and beef. Meat Science, 52, 189-194.

Lytras, G.N., King, R.D., \& Ledward, D.A. (2000). Prediction of the soluble myoglobin content of cooked burgers. Meat Science, 55, 247-250.

Machlik, S.M. (1965). The effect of heat on bovine myoglobin derivatives in model systems and in beef semitendinosus muscle. PhD. Dissertation, ETD Collection for Purdue University, AAI6605286.

Mancini, R.A., \& Hunt, M.C. (2005). Current research in meat color. Meat Science, 71, 100-121.

Mancini, R.A., Kropf, D.H., Hunt, M.C., \& Johnson, D.E. (2005). Effects of endpoint temperature, $\mathrm{pH}$, and storage time on cooked internal color reversion of pork longissimus chops. Journal of Muscle Foods, 16, 16-26.

Mancini, R.A., Ramanathan, R., Suman, S.P., Dady, G., \& Joseph, P. (2011). Effects of succinate on ground beef color and premature browning. Meat Science, 89,189194.

Mancini, R.A., Ramanathan, R., Suman, S.P., Konda, M.K.R., Joseph, P., Dady, G., Naveena, B.M., \& López-López, I. (2010). Effects of lactate and modified atmospheric packaging on premature browning in cooked ground beef patties. Meat Science, 85, 339-346.

Mancini, R.A., Suman, S.P., Konda, M.K.R., \& Ramanathan, R. (2009). Effect of carbon monoxide packaging and lactate enhancement on the color stability of beef steaks stored at $1^{\circ} \mathrm{C}$ for 9 days. Meat science, $81,71-76$.

Marksberry, C.L. (1990). The effect of fat level, $\mathrm{pH}$, carcass maturity and compaction on the cooked internal color of ground beef patties at five end-point temperatures. M.S. thesis, Kansas State Univ., Manhattan.

McKenna, D.R., Mies, P.D., Baird, B.E., Pfeiffer, K.D., Ellebracht, J.W., \& Savell, J.W. (2005). Biochemical and physical factors affecting discoloration characteristics of 19 bovine muscles. Meat Science, 70, 665-682.

McMillin, K.W. (2008). Where is MAP going? A review and future potential of modified atmosphere packaging for meat. Meat Science, 80, 43-65.

Mendenhall, V.T. (1989). Effect of $\mathrm{pH}$ and total pigment concentration on the internal color of cooked ground beef patties. Journal of Food Science, 54, 1-2.

Moeller, S.J., Miller, R.K., Edwards, K.K., Zerby, H.N., Logan, K.E., Aldredge, T.L., Stahl, C.A., Boggess, M., \& Box-Steffensmeier, J.M. (2010). Consumer perceptions of pork eating quality as affected by pork quality attributes and endpoint cooked temperature. Meat Science, 84, 14-22.

Moiseev, I.V., \& Cornforth, D. P. (1999). Treatments for prevention of persistent pinking in dark-cutting beef patties. Journal of Food Science, 64, 738-743.

Mottram, D.S. (1998). Flavour formation in meat and meat products: a review. Food Chemistry, 62, 415-424.

Nair, M.N., Suman, S.P., Li, S., Ramanathan, R., \& Mancini, R.A. (2014). Temperatureand $\mathrm{pH}$-dependent effect of lactate on in vitro redox stability of red meat myoglobins. Meat Science, 96, 408-412.

Nalivka, J. (2003). Meat and poultry facts. American Meat Institute, Washington, DC, USA. 
Nam, K.C., \& Ahn, D.U. (2002a). Carbon monoxide-heme pigment is responsible for the pink color in irradiated raw turkey breast meat. Meat Science, 60, 25-33.

Nam, K.C., \& Ahn, D.U. (2002b). Mechanisms of pink color formation in irradiated precooked turkey breast meat. Journal of Food Science, 67, 600-607.

Nam, K.-C., Jo, C., \& Lee, M. (2010). Meat products and consumption culture in the East. Meat Science, 86, 95-102.

Nam, Y.J., Choi, Y.M., Lee, S.H., Choe, J.H., Jeong, D.W., Kim, Y.Y., \& Kim, B.C. (2009). Sensory evaluations of porcine longissimus dorsi muscle: Relationships with postmortem meat quality traits and muscle fiber characteristics. Meat Science, 83, 731-736.

NCBA. (2010). National Cattlemen's Beef Association. http://www.beefresearch.org/CMDocs/BeefResearch/MR_Executive\%20Summari es/Consumer_Perceptions_of_Beef_Safety.pdf

Norman, J.L., Berg, E.P., Heymann, H., \& Lorenzen, C.L. (2003). Pork loin color relative to sensory and instrumental tenderness and consumer acceptance. Meat Science, 65, 927-933.

NPPC. (2000). National Pork Producers Council. http://www.pork.org/wpcontent/uploads/2010/04/trichinella.pdf

Nusimovich, A.D., Celmi, R.A., \& Pagliaro, A.F. (1979). Colour determination of beef juices as an indicator of beef cooking temperatures. Meat Science, 3, 233-244.

Orta-Ramirez, A., Wang, C.H., Abouzied, M.M., Veeramuthu, G.J., Price, J.F., Pestka, J.J., \& Smith, D.M. (1996). Lactate dehydrogenase monoclonal antibody sandwich ELISA to determine cooking temperature of ground beef. Journal of Agricultural and Food Chemistry, 44, 4048-4051.

Page, J.K., Wulf, D.M., \& Schwotzer, T.R. (2001). A survey of beef muscle color and pH. Journal of Animal Science, 79, 678-687.

Pakula, C., \& Stamminger, R. (2012). Measuring changes in internal meat colour, colour lightness and colour opacity as predictors of cooking time. Meat Science, 90, 721727.

Papadopoulos, L.S., Miller, R.K., Ringer, L.J., \& Cross, H.R. (1991). Sodium lactate effect on sensory characteristics, cooked meat color and chemical composition. Journal of Food Science, 56, 621-626.

Phang, H.S., \& Bruhn, C.M. (2011). Burger preparation: what consumers say and do in the home. Journal of Food Protection, 74, 1708-1716.

Phillips, A.L., Mancini, R., Sun, Q., Lynch, M.P., \& Faustman, C. (2001). Effect of erythorbic acid on cooked color in ground beef. Meat Science, 57, 31-34.

Ramanathan, R., Mancini, R.A., Dady, G.A., \& Van Buiten, C.B. (2013). Effects of succinate and $\mathrm{pH}$ on cooked beef color. Meat Science, 93, 888-892.

Riley, L.W., Remis, R.S., Helgerson, S.D., McGee, H.B., Wells, J.G., Davis, B.R., Hebert, R.J., Olcott, E.S., Johnson, L.M., \& Hargrett, N.T. (1983). Hemorrhagic colitis associated with a rare Escherichia coli serotype. New England Journal of Medicine, 308, 681-685.

Rojas, M.C., \& Brewer, M.S. (2007). Effect of natural antioxidants on oxidative stability of cooked, refrigerated beef and pork. Journal of Food Science, 72, S282-S288. 
Rossvoll, E., Sorheim, O., Heir, E., Moretro, T., Olsen, N.V., \& Langsrud, S. (2014). Consumer preferences, internal color and reduction of shigatoxigenic Escherichia coli in cooked hamburgers. Meat Science, 96, 695-703.

Rossvoll, E.H., Lavik, R., Ueland, O., Jacobsen, E., Hagtvedt, T., \& Langsrud, S. (2013). Food safety practices among Norwegian consumers. Journal of Food Protection, 76, 1939-1947.

Ryan, S.M., Seyfert, M., Hunt, M.C., \& Mancini, R.A. (2006). Influence of cooking rate, endpoint temperature, post-cook hold time, and myoglobin redox state on internal color development of cooked ground beef patties. Journal of Food Science, 71, C216-C221.

Ryu, K.S. Shim, K.S., \& Shin, D.K. (2014). Effect of grape pomace powder addition on tbars and color of cooked pork sausages during storage. Korean Journal for Food Science of Animal Resources. 34, 200-206.

Sair, A.I., Booren, A.M., Berry, B.W., \& Smith, A.M. (1999). Residual triose phosphate isomerase activity and color measurements to determine adequate cooking of ground beef patties. Journal of Food Protection, 62, 156-161.

Sammel, L.M., \& Claus, J.R. (2003a). Citric acid and sodium citrate effects on reducing pink color defect of cooked intact turkey breasts and ground turkey rolls. Journal of Food Science, 68, 874-878.

Sammel, L.M., \& Claus, J.R. (2003b). Whey protein concentrates effects on pink color development in a cooked ground turkey breast model system. Meat Science, 65, 1293-1299.

Sammel, L.M., \& Claus, J.R. (2007). Calcium chloride and tricalcium phosphate effects on the pink color defect in cooked ground and intact turkey breast. Meat Science, 77, 492-498.

Sammel, L.M., Claus, J.R., Greaser, M.L., \& Lucey, J.A. (2007). Identifying constituents of whey protein concentrates that reduce the pink color defect in cooked ground turkey. Meat Science, 77, 529-539.

Sammel, L.M., Claus, J.R., Greaser, M.L., \& Richards, M.P. (2006). Investigation of mechanisms by which sodium citrate reduces the pink color defect in cooked ground turkey. Meat science, 72, 585-595.

Sasse, A., Colindres, P., \& Brewer, M.S. (2009). Effect of natural and synthetic antioxidants on the oxidative stability of cooked, frozen pork patties. Journal of Food Science, 74, S30-S35.

Sawyer, J.T., Apple, J.K., \& Johnson, Z.B. (2008). The impact of lactic acid concentration and sodium chloride on $\mathrm{pH}$, water-holding capacity, and cooked color of injection-enhanced dark-cutting beef. Meat Science, 79, 317-325.

Sawyer, J.T., Apple, J.K., Johnson, Z.B., Baublits, R.T., \& Yancey, J.W.S. (2009). Fresh and cooked color of dark-cutting beef can be altered by post-rigor enhancement with lactic acid. Meat Science, 83, 263-270.

Schwarz, S.J., Claus, J.R., Wang, H., Marriott, N.G., Graham, P.P., \& Fernandes, C.F. (1997). Inhibition of pink color development in cooked, uncured ground turkey through the binding of non-pink generating ligands to muscle pigments. Poultry Science, 76, 1450-1456. 
Schwarz, S.J., Claus, J.R., Wang, H., Marriott, N.G., Graham, P.P., \& Fernandes, C.F. (1999). Inhibition of pink color development in cooked, uncured turkey breast through ingredient incorporation. Poultry Science, 78, 255-266.

Scopes, R.K. (1964). The influence of post mortem conditions on the solubilities of muscle proteins. Biochemical Journal. 92, 201-207.

Sepe, H.A., Faustman, C., Lee, S., Tang, J., Suman, S.P., \& Venkitanarayanan, K.S. (2005). Effects of reducing agents on premature browning in ground beef. Food Chemistry, 93, 571-576.

Seyfert, M., Hunt, M.C., Mancini, R.A., Kropf, D.H., \& Stroda, S.L. (2004a). Internal premature browning in cooked steaks from enhanced beef round muscles packaged in high-oxygen and ultra-low oxygen modified atmospheres. Journal of Food Science, 69, fct142-fct146.

Seyfert, M., Mancini, R.A., \& Hunt, M.C. (2004b). Internal premature browning in cooked ground beef patties from high-oxygen modified-atmosphere packaging. Journal of Food Science, 69, C721-C725.

Seyfert, M., Mancini, R.A., Hunt, M.C., Tang, J., Faustman, C., \& Garcia, M. (2006). Color stability, reducing activity, and cytochrome c oxidase activity of five bovine muscles. Journal of Agricultural and Food Chemistry, 54, 8919-8925.

Shackelford, S.D., Koohmaraie, M., Wheeler, T.L., Cundiff, L.V., \& Dikeman, M.E. (1994). Effect of biological type of cattle on the incidence of the dark, firm, and dry condition in the longissimus muscle. Journal of Animal Science, 72, 337-343.

Shah, M. A., Bosco, S. J. D., \& Mir, S. A. (2014). Plant extracts as natural antioxidants in meat and meat products. Meat science, 98(1), 21-33.

Slesinski, A.J., Claus, J.R., Anderson-Cook, C.M., Eigel, W.E., Graham, P.P., Lenz, G.E., \& Noble, R.B. (2000a). Ability of various dairy proteins to reduce pink color development in cooked ground turkey breast. Journal of Food Science, 65, 417-420.

Slesinski, A.J., Claus, J.R., Anderson-Cook, C.M., Eigel, W.E., Graham, P.P., Lenz, G.E., \& Noble, R.B. (2000b). Response surface methodology for reduction of pinking in cooked turkey breast mince by various dairy protein combinations. Journal of Food Science, 65, 421-427.

Sorheim, O., \& Hoy, M. (2013). Effects of food ingredients and oxygen exposure on premature browning in cooked beef. Meat Science, 93, 105-110.

Stalder, J.W., Smith, G.L., Keeton, J.T., \& Smith, S. B.(1991). Lactate dehydrogenase activity in bovine muscle as a means of determining heating endpoint. Journal of Food Science, 56, 895-898.

Stalder, J.W., Smith, G.L., Keeton, J.T., \& Smith, S.B. (1997). Lactate dehydrogenase activity as an endpoint heating indicator in cooked beef. Journal of Food Science, 62, 316-320.

Suman, S.P., \& Joseph, P. (2013). Myoglobin chemistry and meat color. Annual Review of Food Science and Technology, 4, 79-99.

Suman, S.P., \& Joseph, P. (2014). Chemical and physical characteristics of meat: Color and pigment. In (Eds) Dikeman, M.and Devine, C. Encyclopedia of Meat Sciences. ${ }^{\text {nd }}$ Ed: Elsevier, Oxford, United Kingdom. Vol 3. Chapter 84, pp. 244251. 
Suman, S.P., Faustman, C., Lee, S., Tang, J., Sepe, H.A., Vasudevan, P., Annamalai, T., Manojkumar, M., Marek, P., DeCesare, M., \& Venkitanarayanan, K.S. (2004). Effect of muscle source on premature browning in ground beef. Meat Science, 68, 457-461.

Suman, S.P., Faustman, C., Lee, S., Tang, J., Sepe, H.A., Vasudevan, P., Annamalai, T., Manojkumar, M., Marek, P., \& Venkitanarayanan, K.S. (2005). Effect of erythorbate, storage and high-oxygen packaging on premature browning in ground beef. Meat Science, 69, 363-369.

Suman, S.P., Faustman, C., Stamer, S.L., \& Liebler, D.C. (2007). Proteomics of lipid oxidation-induced oxidation of porcine and bovine oxymyoglobins. Proteomics, 7, 628-640.

Suman, S.P., Hunt, M.C., Nair, M.N., \& Rentfrow, G. (2014). Improving beef color stability: Practical strategies and underlying mechanisms. Meat Science, 98, 490504.

Suman, S.P., Mancini, R.A, Ramanathan, R., \& Konda, M.R. (2009). Effect of lactateenhancement, modified atmosphere packaging, and muscle source on the internal cooked colour of beef steaks. Meat science, 81, 664-670.

Suman, S.P., Mancini, R.A., \& Faustman, C. (2006). Lipid-oxidation-induced carboxymyoglobin oxidation. Journal of Agricultural and Food Chemistry, 54, 9248-9253.

Suman, S.P., Mancini, R.A., Joseph, P., Ramanathan, R., Konda, M.K.R., Dady, G., \& Yin, S. (2011). Chitosan inhibits premature browning in ground beef. Meat Science, 88, 512-516.

Suman, S.P., Mancini, R.A., Ramanathan, R., \& Konda, M.R. (2010). Modified atmosphere packaging influences premature browning in beef Longissimus lumborum steaks. Fleischwirtschaft international, 3, 54-55.

Swan, J.E., \& Boles, J.A. (2002). Processing characteristics of beef roasts made from high and normal pH bull inside rounds. Meat Science, 62, 399-403.

Tappel, A.L. (1957). Reflectance spectral studies of the hematin pigments of cooked beef. Journal of Food Science, 22, 404-407.

Tarladgis, B.G. (1962). Interpretation of the spectra of meat pigments. 1.-cooked meats. Journal of the Science of Food and Agriculture, 13, 481-484.

Trout, G.R. (1989). Variation in myoglobin denaturation and color of cooked beef, pork, and turkey meat as influenced by $\mathrm{pH}$, sodium chloride, sodium tripolyphosphate, and cooking temperature. Journal of Food Science, 54, 536-540.

Troutt, E.S., Hunt, M.C., Johnson, D.E., Claus, J.R., Kastner, C.L., Kropf, D.H., \& Stroda, S. (1992). Chemical, physical, and sensory characterization of ground beef containing 5 to 30 percent fat. Journal of Food Science, 57, 25-29.

Ueki, N., \& Ochiai, Y. (2004). Primary structure and thermostability of bigeye tuna myoglobin in relation to those of other scombridae fish. Fisheries Science, 70, 875-884.

Ueki, N., Chow, C.J., \& Ochiai, Y. (2005). Characterization of bullet tuna myoglobin with reference to the thermostability-structure relationship. Journal of Agricultural and Food Chemistry, 53, 4968-4975.

USDA (United States Department of Agriculture). (2013) Color of cooked ground beef as it relates to doneness. USDA Fact Sheet last modified August 2013. 
http://www.fsis.usda.gov/wps/portal/fsis/topics/food-safety-education/getanswers/food-safety-fact-sheets/meat-preparation/color-of-cooked-ground-beefas-it-relates-to-doneness/ct_index

USDA. (1997). USDA advises consumers to use a meat thermometer when cooking hamburger. FSIS News and Information Bulletin. FSIS. USDA. Washington, DC.

USDA. (1999). Appendix A. Compliance Guidelines for Meeting Lethality Performance Standards for Certain Meat and Poultry Products. Federal Register: January 6, 1999 Volume 64, Number 3, pages 732-749.

Van Laack, R.L.J.M., Berry, B.W., \& Solomon, M.B. (1996a). Effect of precooking conditions on color of cooked beef patties. Journal of Food Protection, 59, 976983.

Van Laack, R.L.J.M., Berry, B.W., \& Solomon, M.B. (1996b). Variations in internal color of cooked beef patties. Journal of Food Science, 61, 410-414.

Van Laack, R.L.J.M., Berry, B.W., \& Solomon, M.B. (1997). Cooked color of patties processed from various combinations of normal or high $\mathrm{pH}$ beef and lean finely textured beef. Journal of Muscle Foods, 8, 287-299.

Vittadini, E., Rinaldi, M., Chiavaro, E., Barbanti, D., \& Massini, R. (2005). The effect of different convection cooking methods on the instrumental quality and yield of pork Longissimus dorsi. Meat Science, 69, 749-756.

Voisinet, B.D., Grandin, T., O'Connor, S.F., Tatum, J.D., \& Deesing, M.J. (1997). Bos indicus-cross feedlot cattle with excitable temperaments have tougher meat and a higher incidence of borderline dark cutters. Meat Science, 46, 367-377.

Wang, C., \& Brewer, M.S. (1999). Sodium lactate/sodium polyphosphate effects on oxidation in precooked frozen pork patties. Journal of Muscle Foods, 10, 147162.

Wang, S.S., Abouzied, M.M., \& Smith, D.M. (1996). Proteins as potential endpoint temperature indicators for ground beef patties. Journal of Food Science, 61, 5-7.

Warren, K.E., Hunt, M.C., \& Kropf, D.H. (1996a). Myoglobin oxidative state affects internal cooked color development in ground beef patties. Journal of Food Science, 61, 513-515.

Warren, K.E., Hunt, M.C., Kropf, D.H., Hague, M.A., Waldner, C.L., Stroda, S.L., \& Kastner, C.L. (1996b). Chemical properties of ground beef patties exhibiting normal and premature brown internal cooked color. Journal of Muscle Foods, 7, 303-314.

Wettasinghe, M., \& Shahidi, F. (1997). Oxidative stability, cooking yield and texture of pork treated with a low-sodium salt. Journal of Muscle Foods, 8(4), 373-382.

WHO (2011). Enterohaemorrhagic Escherichia coli (EHEC), fact sheet. http://www.who.int/mediacentre/factsheets/fs 125/en/

Wicklund, R.A., Paulson, D.D., Tucker, E.M., Stetzer, A.J., DeSantos, F., Rojas, M., MacFarlane, B.J., \& Brewer, M.S. (2006). Effect of carbon monoxide and high oxygen modified atmosphere packaging and phosphate enhanced, case-ready pork chops. Meat Science, 74, 704-709.

Wills, C. T. (2004). Factors, prevention, and predictability of the pink color defect in uncured fully cooked chicken breast meat. M.S. Thesis, The University of Georgia. 
Wold, J.P. (2016). On-line and non-destructive measurement of core temperature in heat treated fish cakes by NIR hyperspectral imaging. Innovative Food Science \& Emerging Technologies, 33, 431-437.

Xia, J., Weaver, A., Gerrard, D.E., \& Yao, G. (2008). Heating induced optical property changes in beef muscle. Journal of Food Engineering, 84, 75-81.

Yancey, J.W.S., Wharton, M.D., \& Apple, J.K. (2011). Cookery method and end-point temperature can affect the Warner-Bratzler shear force, cooking loss, and internal cooked color of beef longissimus steaks. Meat Science, 88, 1-7.

Yin, S., Faustman, C., Tatiyaborworntham, N., Ramanathan, R., Naveena, B.M., Mancini, R. A., Joseph, P., Suman, S. P., \& Sun, Q. (2011). Species-specific myoglobin oxidation. Journal of Agricultural and Food Chemistry, 59, 1219812203.

Young, L.L., \& Lyon, C.E. (1997). Effect of postchill aging and sodium tripolyphosphate on moisture binding properties, color, and Warner-Bratzler shear values of chicken breast meat. Poultry Science, 76, 1587-1590. 
Figure 1 - A schematic representation of the fundamental mechanisms through which myoglobin primary structure influences cooked color.

Reproduced from Suman and Joseph (2013) with permission.

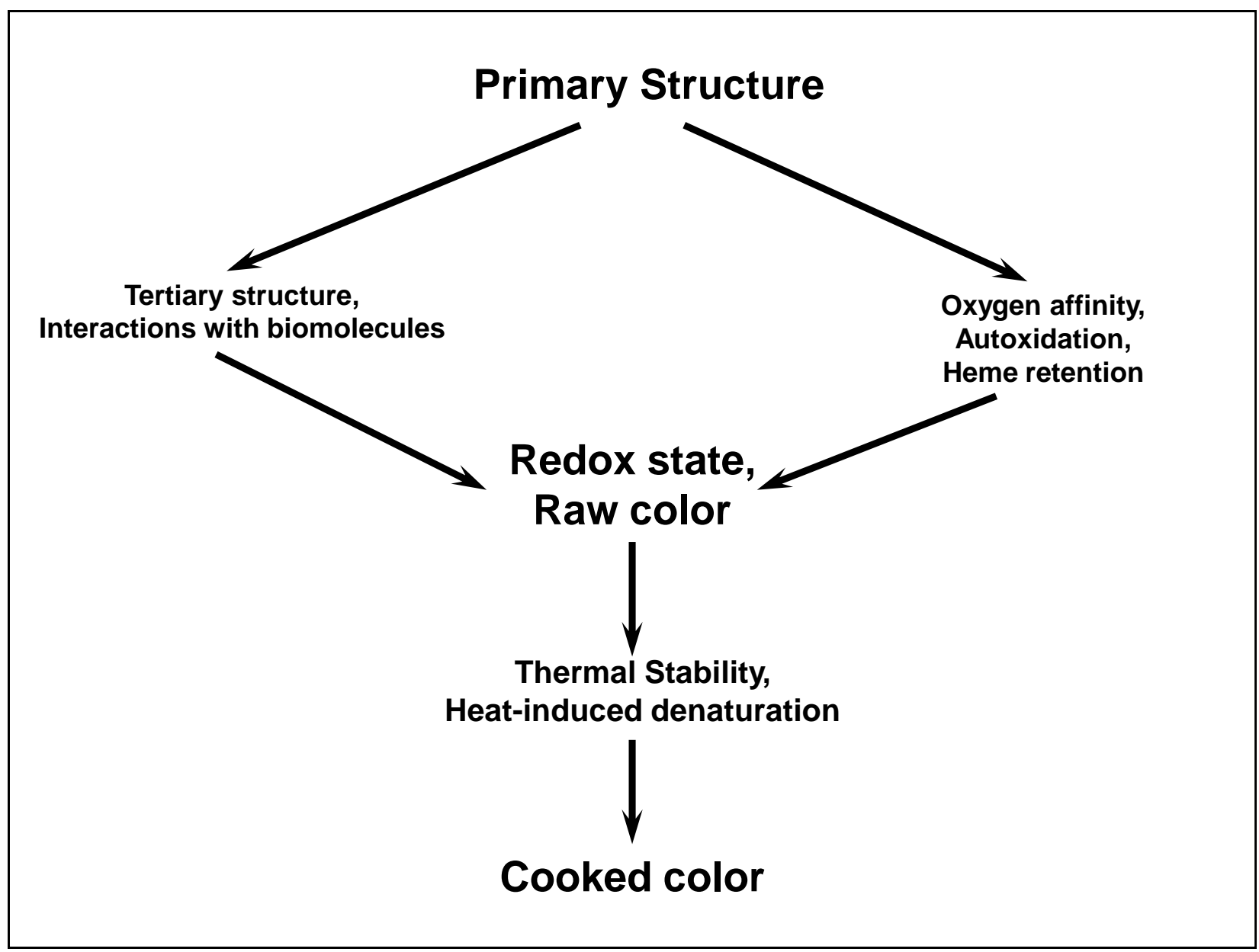


Figure 2 - Percentage myoglobin denaturation in beef myoglobin at $71^{\circ} \mathrm{C}$ in the presence of $200 \mathrm{mM}$ sodium lactate.

${ }^{\mathrm{a}-\mathrm{d}}$ Means without a common letter are different $(\mathrm{P}<0.05)$.

Reproduced from Nair et al. (2014) with permission.

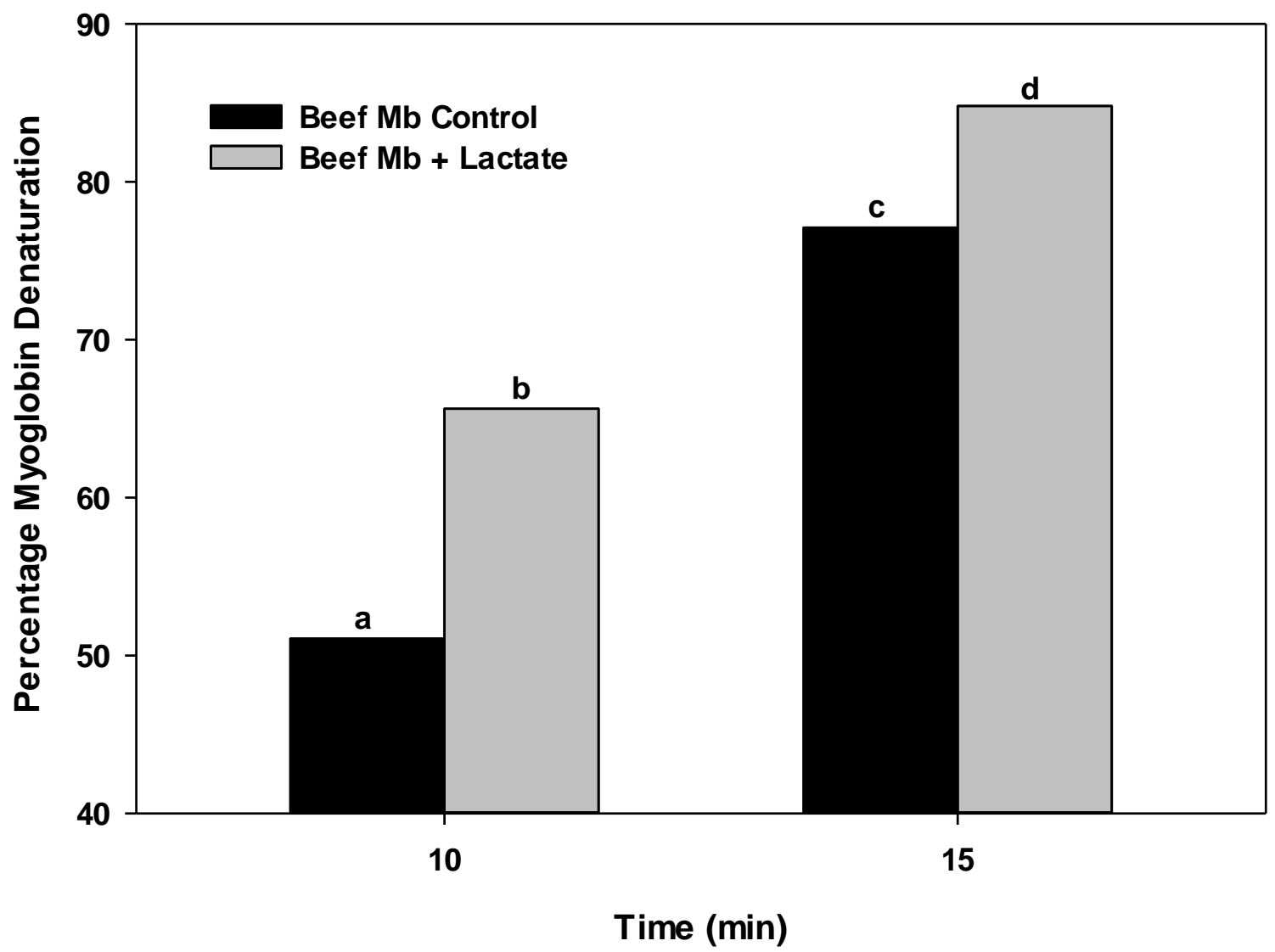


Figure 3 - MALDI-TOF mass spectra of turkey and beef myoglobins.

Reproduced from Joseph et al. (2010) with permission.

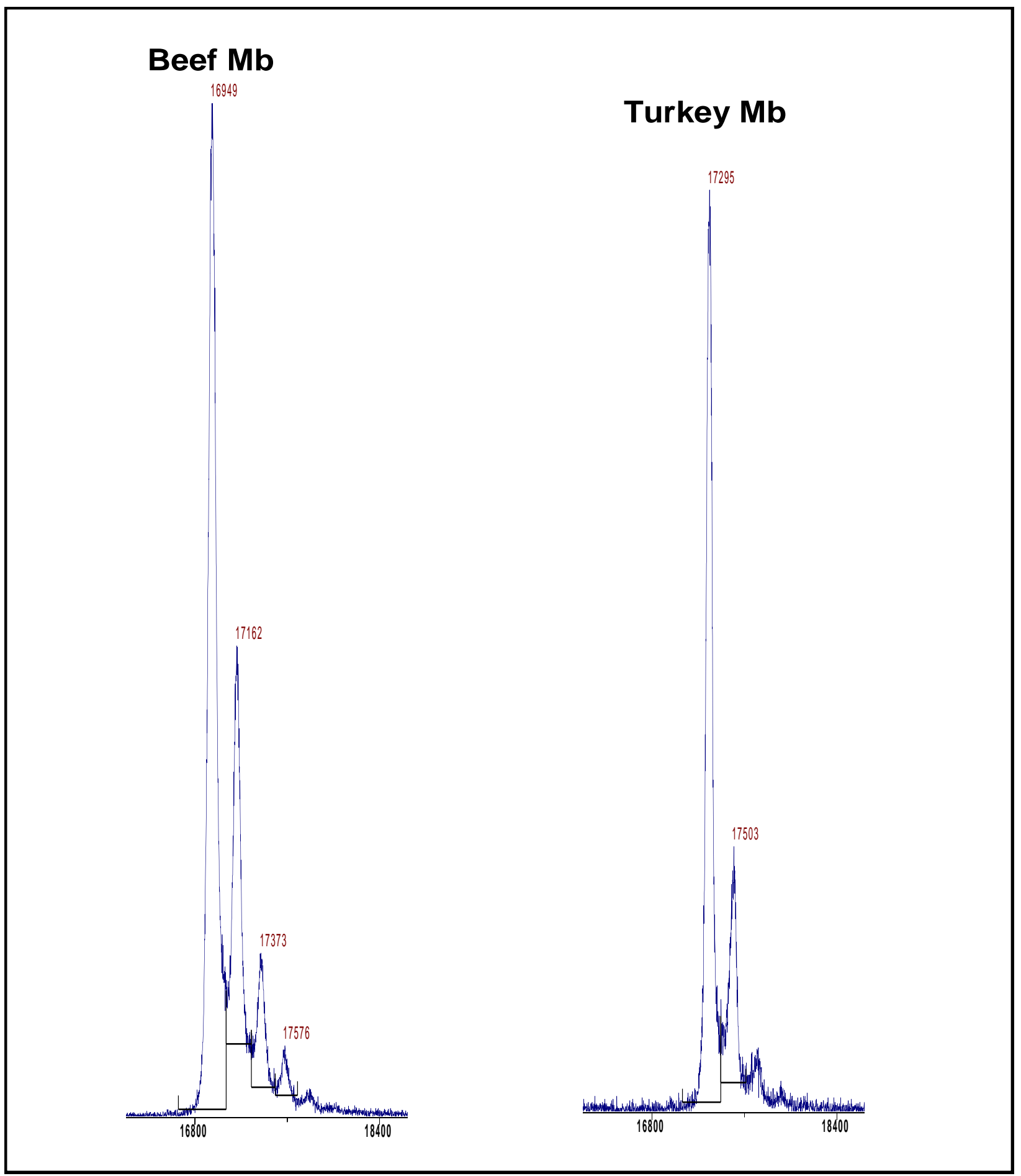


Table 1 - Biochemistry of pigments in cooked meats

Reproduced from Suman and Joseph (2014) with permission

\begin{tabular}{|c|c|c|c|c|c|}
\hline Pigment & Meat species & Color & $\begin{array}{l}\text { Oxidation } \\
\text { state of } \\
\text { heme iron }\end{array}$ & $\begin{array}{l}\text { Status of } \\
\text { globin }\end{array}$ & Reference \\
\hline $\begin{array}{l}\text { Denatured globin } \\
\text { hemochrome }\end{array}$ & $\begin{array}{l}\text { Cooked pork or } \\
\text { beef }\end{array}$ & Pink or red & $\mathrm{Fe}^{2+}$ & Denatured & $\begin{array}{l}\text { Tappel (1957); Ghorpade \& Cornforth } \\
\text { (1993) }\end{array}$ \\
\hline $\begin{array}{l}\text { Denatured globin } \\
\text { hemichrome }\end{array}$ & Cooked pork & $\begin{array}{l}\text { Brown, tan } \\
\text { or gray }\end{array}$ & $\mathrm{Fe}^{3+}$ & Denatured & Tarladgis (1962) \\
\hline $\begin{array}{l}\text { Nicotinamide } \\
\text { hemochrome }\end{array}$ & Turkey & Pink or red & $\mathrm{Fe}^{2+}$ & Denatured & Tappel (1957); Cornforth et al (1986) \\
\hline $\begin{array}{l}\text { Denatured globin } \mathrm{CO} \\
\text { hemochrome }\end{array}$ & Cooked beef & Pink or red & $\mathrm{Fe}^{2+}$ & Denatured & Tappel (1957); John et al (2004) \\
\hline
\end{tabular}


Table 2 - Influence of meat $\mathrm{pH}$ and redox state on myoglobin thermal stability and internal cooked color

\begin{tabular}{|c|c|c|}
\hline Reference & Meat species & Observation \\
\hline Scopes (1964); Lawrie (1965) & Beef, pork & $\begin{array}{l}\text { Pre-rigor conditions that affect the rate of } \mathrm{pH} \text { decline to } \mathrm{pH}<5.4 \text { will lower } \\
\mathrm{Mb} \text { thermal stability, which can lead to increased browning }\end{array}$ \\
\hline Trout (1989) & $\begin{array}{l}\text { Beef, pork, and } \\
\text { turkey }\end{array}$ & High $\mathrm{pH}$ decreased $\mathrm{Mb}$ denaturation in cooked meats \\
\hline Mendenhall (1989) & Beef & High $\mathrm{pH}$ minimized $\mathrm{Mb}$ denaturation in ground beef \\
\hline Marksberry (1990) & Beef & $\mathrm{pH} \leq 5.75$ exerted no influence on cooked beef color \\
\hline Hague et al. (1994) & Beef & Meat $\mathrm{pH}$ values at normal range $(5.5-5.75)$ had no effect on cooked color \\
\hline Van Laack et al. (1996b) & Beef & Strong negative correlation between $\mathrm{pH}$ and $\mathrm{Mb}$ denaturation \\
\hline Berry $(1998 a, b)$ & Beef & High $\mathrm{pH}$ can cause persistent pink appearance in cooked meats \\
\hline Lavelle et al. (1995) & Beef & $\begin{array}{l}\text { Both OxyMb and MetMb denature at low enough temperature to cause } \\
\text { PMB; DeoxyMb thermal stability is sufficient to prevent PMB. }\end{array}$ \\
\hline Bigner-George and Berry (1999) & Beef & $\begin{array}{l}\text { Ground beef formulations with high } \mathrm{pH}(>6.0) \text { could protect } \mathrm{Mb} \text { against } \\
\text { heat induced denaturation }\end{array}$ \\
\hline Brewer and Novakofski (1999) & Beef & $\begin{array}{l}\text { Meat } \mathrm{pH} \text { above normal } \mathrm{pH} \text { increased pinking, whereas low } \mathrm{pH} \text { promoted } \\
\text { browning in cooked meats }\end{array}$ \\
\hline Hunt et al. (1999) & Beef & $\begin{array}{l}\text { Significant interactions between } \mathrm{Mb} \text { redox form, } \mathrm{pH} \text {, and endpoint } \\
\text { temperature on } \mathrm{Mb} \text { thermal stability }\end{array}$ \\
\hline Lytras et al. (1999) & Beef, lamb & The rate of cooked meat pigment formation was inversely proportional to $\mathrm{pH}$ \\
\hline Moiseev and Cornforth (1999) & Beef & $\begin{array}{l}\text { High } \mathrm{pH} \text { patties had lower myoglobin denaturation and greater internal } \\
\text { redness than their normal } \mathrm{pH} \text { counterparts }\end{array}$ \\
\hline Lien et al. (2002a) & Pork & $\begin{array}{l}\text { High } \mathrm{pH} \text { protects } \mathrm{Mb} \text { from heat-induced denaturation and increases red or } \\
\text { pink color after cooking }\end{array}$ \\
\hline Swan and Boles (2002) & Beef & $\begin{array}{l}\text { Roasts from high-pH bull inside rounds exhibited greater internal cooked } \\
\text { redness than normal-pH roasts }\end{array}$ \\
\hline Ballard (2004) & Beef & Thermal stability of COMb was greater than that of for DeoxyMb \\
\hline Mancini et al. (2005) & Pork & $\begin{array}{l}\text { Chops with high } \mathrm{pH} \text { were more red and had more pink color development } \\
\text { during storage than those with low } \mathrm{pH}\end{array}$ \\
\hline
\end{tabular}


Table 3 - Influence of packaging system on internal cooked color and premature browning (PMB) in beef

\begin{tabular}{|c|c|c|}
\hline Reference & Commodity & Observation \\
\hline Ballard (2004) & Beef & $\begin{array}{l}\text { Anoxic packaging in CO MAP eliminates PMB and increases surface } \\
\text { pinking }\end{array}$ \\
\hline Seyfert et al. (2004a) & Steak & High-oxygen MAP increases PMB \\
\hline Seyfert et al. (2004b) & Ground beef & High-oxygen MAP increases PMB \\
\hline John et al. (2004) & Ground beef & CO MAP minimizes PMB \\
\hline John et al. (2005) & Steak & CO MAP minimizes PMB \\
\hline Suman et al. (2005) & Ground beef & $\begin{array}{l}\text { High-oxygen MAP increases PMB compared to aerobic packaging; bulk } \\
\text { packaging increases PMB }\end{array}$ \\
\hline Grobbel et al. (2008) & Steak & High-oxygen MAP increases PMB \\
\hline Suman et al. (2009) & Steak & $\begin{array}{l}\text { High-oxygen MAP increases PMB, whereas CO MAP and vacuum } \\
\text { packaging minimizes PMB }\end{array}$ \\
\hline Mancini et al. (2010) & Ground beef & $\begin{array}{l}\text { High-oxygen MAP increases PMB, whereas CO MAP and vacuum } \\
\text { packaging minimize PMB }\end{array}$ \\
\hline Suman et al. (2010) & Steaks & $\begin{array}{l}\text { High-oxygen MAP increases PMB in beef longissimus, whereas CO MAP } \\
\text { and vacuum packaging minimizes PMB }\end{array}$ \\
\hline Lagerstedt et al. (2011) & Steak & High-oxygen MAP decreases internal redness \\
\hline Suman et al. (2011) & Ground beef & $\begin{array}{l}\text { High-oxygen MAP and aerobic packing increase PMB, whereas CO MAP } \\
\text { and vacuum packaging minimize PMB }\end{array}$ \\
\hline Sorheim and Hoy (2013) & Ground beef & High-oxygen MAP increases PMB; anaerobic packaging minimizes PMB \\
\hline Ramanathan et al. (2013) & Ground beef & $\begin{array}{l}\text { High-oxygen MAP increases PMB, whereas vacuum packaging minimizes } \\
\text { PMB }\end{array}$ \\
\hline Rossvoll et al. (2014) & Ground beef & High-oxygen MAP increases PMB \\
\hline
\end{tabular}


Table 4 - Influence of antioxidants on internal cooked color and premature browning in beef

\begin{tabular}{|c|c|c|}
\hline Reference & Commodity & Observation \\
\hline Lavelle et al. (1995) & Ground beef & Dietary vitamin E supplementation to beef cattle had no effect on PMB \\
\hline Phillips et al. (2001) & Ground beef & Erythorbate minimizes PMB \\
\hline Sepe et al. (2005) & Ground beef & $\begin{array}{l}\text { Erythorbate and ascorbate minimize PMB, whereas ascorbyl palmitate did } \\
\text { not }\end{array}$ \\
\hline Suman et al. (2005) & Ground beef & $\begin{array}{l}\text { Erythorbate prevents PMB in refrigerated and frozen patties, whereas its } \\
\text { effect was minimal in high oxygen MAP }\end{array}$ \\
\hline Suman et al. (2009) & Steak & $\begin{array}{l}\text { Lactate minimizes PMB in longissimus and psoas steaks; the effects of } \\
\text { lactate were pronounced in CO MAP and vacuum packaging and minimal in } \\
\text { high-oxygen MAP }\end{array}$ \\
\hline Kim et al. (2010) & Steaks & $\begin{array}{l}\text { Compared to D-lactate, L-lactate had greater reduction of MetMb, greater } \\
\text { maintenance of DeoxyMb, and less } \mathrm{Mb} \text { thermal denaturation. }\end{array}$ \\
\hline Mancini et al. (2010) & Ground beef & Lactate had no effect on PMB in ground beef \\
\hline Mancini et al. (2011) & Ground beef & $\begin{array}{l}\text { Succinate minimizes PMB in patties stored under aerobic packaging, vacuum } \\
\text { packaging, and high-oxygen MAP }\end{array}$ \\
\hline Suman et al. (2011) & Ground beef & $\begin{array}{l}\text { Chitosan minimizes PMB in patties stored under aerobic packaging, vacuum } \\
\text { packaging and CO MAP, but not in high-oxygen MAP }\end{array}$ \\
\hline Ramanathan et al. (2013) & Ground beef & Succinate minimizes PMB in patties stored under aerobic packaging \\
\hline Sorheim and Hoy (2013) & $\begin{array}{l}\text { Ground beef and } \\
\text { steak }\end{array}$ & $\begin{array}{l}\text { Sodium polyphosphate decreased PMB, possibly through increasing the meat } \\
\mathrm{pH}\end{array}$ \\
\hline
\end{tabular}


Table 5 - Influence of other exogenous and endogenous factors on internal cooked color and premature browning in beef

\begin{tabular}{|c|c|c|}
\hline Reference & Influencing factor & Observation \\
\hline Troutt et al. (1992) & Fat content & $\begin{array}{l}\text { Fat content }(5-30 \%) \text { did not influence internal redness of cooked } \\
\text { ground beef patties }\end{array}$ \\
\hline Van Laack et al. (1996a) & Thawing & $\begin{array}{l}\text { Longer thawing period increased PMB compared to shorter thawing } \\
\text { periods }\end{array}$ \\
\hline Liu and Berry (1996) & Fat content & $\begin{array}{l}\text { Ground beef patties with } 20 \% \text { fat demonstrated a greater degree of } \\
\text { doneness than those with } 10 \% \text { fat after cooking to } 71^{\circ} \mathrm{C}\end{array}$ \\
\hline Bigner-George and Berry (2000a) & Thawing & $\begin{array}{l}\text { Thawing frozen patties prior to cooking decreased the internal } \\
\text { redness }\end{array}$ \\
\hline Bigner-George and Berry (2000b) & $\begin{array}{l}\text { Thawing and fat } \\
\text { content }\end{array}$ & $\begin{array}{l}\text { Thawing frozen patties prior to cooking decreased the internal } \\
\text { redness; increase in fat content decreased the internal redness }\end{array}$ \\
\hline Killinger et al. (2000) & Bulk package & $\begin{array}{l}\text { Location of ground beef within the bulk package affected incidence } \\
\text { of PMB }\end{array}$ \\
\hline Suman et al. (2004) & Muscle source & $\begin{array}{l}\text { Patties prepared from psoas major are less prone to PMB than those } \\
\text { from longissimus muscle }\end{array}$ \\
\hline Seyfert et al. (2004a) & Muscle source & $\begin{array}{l}\text { Rectus femoris steaks demonstrated greater internal cooked redness } \\
\text { than those from vastus lateralis }\end{array}$ \\
\hline Suman et al. (2005) & Storage conditions & $\begin{array}{l}\text { Bulk packaging and thawing increases the incidence of PMB, } \\
\text { whereas cooking frozen patties (without thawing) minimized PMB }\end{array}$ \\
\hline Ryan et al. (2006) & Cooking rate & $\begin{array}{l}\text { Slow-cooked beef patties are more prone to PMB than the rapidly } \\
\text { cooked patties }\end{array}$ \\
\hline Suman et al. (2009) & Muscle source & $\begin{array}{l}\text { Psoas major steaks demonstrate greater internal redness than } \\
\text { longissimus steaks when cooked to same temperature }\end{array}$ \\
\hline Yancey et al. (2011) & Cooking method & $\begin{array}{l}\text { Cooking steaks in clam-shell grills increases the incidence of PMB, } \\
\text { whereas use of force air oven minimizes PMB in steaks }\end{array}$ \\
\hline Bowers et al. (2012) & Cooking method & $\begin{array}{l}\text { Beef roasts cooked in Blodgett convection oven had greater internal } \\
\text { redness than roasts cooked in CVap steam generation oven }\end{array}$ \\
\hline
\end{tabular}


Table 6 - Influence of endogenous factors on cooked color in pork chops

\begin{tabular}{lll}
\hline Reference & Endogenous factor & Observation \\
\hline Lewis et al. (1987) & Fresh pork quality & $\begin{array}{l}\text { DFD pork chops demonstrated lower doneness score (more pink } \\
\text { color) than normal chops } \\
\text { Sensory analyses indicted that cooked chops from males were darker } \\
\text { than their counterparts from female pigs }\end{array}$ \\
Lien et al. (2002a) & Sex of pigs & $\begin{array}{l}\text { Fresh pork quality } \\
\text { DFD pork chops demonstrated more pink color than normal and } \\
\text { LSE chops }\end{array}$ \\
Nam et al. (2002b) & Fresh pork quality & $\begin{array}{l}\text { Patties from PSE pork had lower redness and greater Mb } \\
\text { denaturation than those from normal pork }\end{array}$ \\
Cuscle fiber & $\begin{array}{l}\text { Color cooked pork longissimus muscle demonstrated positive } \\
\text { correlation with muscle fiber density and negative correlation with } \\
\text { cross-sectional area }\end{array}$ \\
\hline
\end{tabular}


Table 7 - Influence of exogenous factors on cooked color in pork products

\begin{tabular}{|c|c|c|}
\hline Reference & Exogenous factor & Observation \\
\hline Hamouz et al. (1996) & Cooking method & Broiling decreased internal redness in chops compared to grilling \\
\hline Wettasinghe and Shahidi (1997) & Addition of salt & $\begin{array}{l}\text { Salt or low-sodium salt mixture exerted no effect on internal cooked color } \\
\text { of ground pork patties }\end{array}$ \\
\hline Wang and Brewer (1999) & Ingredient & Sodium lactate decreased internal redness in cooked ground pork patties \\
\hline Lien et al. (2002b) & Storage & $\begin{array}{l}\text { Ground pork patties cooked directly from frozen state exhibited lower } \\
\text { internal redness than those cooked after thawing }\end{array}$ \\
\hline Fernandez-Lopez et al. (2003) & Ingredient & $\begin{array}{l}\text { Extracts of hyssop and rosemary stabilized the internal red color of cooked } \\
\text { pork patties }\end{array}$ \\
\hline Vittadini et al. (2005) & Cooking method & $\begin{array}{l}\text { Cooking pork chops under Forced Convection/Steam combined conditions } \\
\text { decreased surface redness compared to those cooked employing forced } \\
\text { convection or natural convection method }\end{array}$ \\
\hline Wicklund et al. (2006) & Packaging & $\begin{array}{l}\text { Chops packaged in CO-MAP exhibited greater internal pink color than their } \\
\text { counterparts in high-oxygen MAP }\end{array}$ \\
\hline Rojas and Brewer (2007) & Ingredients & $\begin{array}{l}\text { Natural antioxidants, such as grape seed extract and oregano extract, had no } \\
\text { effect on cooked color of pork patties }\end{array}$ \\
\hline Carpenter et al. (2007) & Ingredients & Grape seed extract increased the surface redness in cooked pork patties \\
\hline De Santos et al. (2007) & Packaging & $\begin{array}{l}\text { Chops packaged in CO-MAP exhibited greater internal pink color than their } \\
\text { counterparts in high-oxygen MAP and aerobic packaging }\end{array}$ \\
\hline Sasse et al. (2008) & Ingredients & Grape seed extract had no effect on redness of cooked frozen pork patties \\
\hline Chiavaro et al. (2009) & Cooking method & $\begin{array}{l}\text { Cooking pork chops under Forced Convection/Steam combined conditions } \\
\text { decreased surface redness compared to those cooked employing forced } \\
\text { convection method }\end{array}$ \\
\hline Kong et al. (2010) & Ingredients & Rosemary and clove extracts maintained the red color in cooked pork patties \\
\hline Dai et al. (2013) & Cooking method & $\begin{array}{l}\text { Loin chops subjected to ohmic cooking demonstrated greater internal } \\
\text { redness than those cooked in water bath at } 70^{\circ} \mathrm{C} \text { and } 80^{\circ} \mathrm{C} \text { internal endpoint } \\
\text { temperatures }\end{array}$ \\
\hline Ryu et al. (2014) & Ingredients & $\begin{array}{l}\text { Grape skin and seed pomace increased internal cooked redness of cooked } \\
\text { pork sausage }\end{array}$ \\
\hline
\end{tabular}


Table 8 - Influence of milk-derived ingredients on pink color defect in fully cooked, uncured poultry products

\begin{tabular}{|c|c|c|}
\hline Reference & Ingredient & Observation \\
\hline Dobson and Cornforth (1992) & Nonfat dry milk & $\begin{array}{l}\text { Pink discoloration in turkey rolls is minimized by incorporating } 3 \% \text { nonfat } \\
\text { dry milk in the formulation }\end{array}$ \\
\hline Schwarz et al. (1997) & Nonfat dry milk & $\begin{array}{l}\text { Nonfat dry milk is effective to decrease pinking induced by nicotinamide and } \\
\text { sodium nitrite in ground turkey products }\end{array}$ \\
\hline Schwarz et al. (1999) & Nonfat dry milk & $\begin{array}{l}\text { In whole muscle products, nonfat dry milk minimizes nicotinamide-induced } \\
\text { pinking, but is not effective in nitrite-induced pinking }\end{array}$ \\
\hline Schwarz et al. (2000) & Nonfat dry milk & Pinking in cooked ground turkey can be prevented by nonfat dry milk \\
\hline Slesinski et al. (2000a) & Sodium caseinate & $\begin{array}{l}\text { Minimized nicotinamide-induced pinking, but not effective in nitrite induced } \\
\text { pinking }\end{array}$ \\
\hline Slesinski et al. (2000a) & $\begin{array}{l}\text { Milk protein } \\
\text { concentrate }\end{array}$ & Limited effect in nitrite induced pinking \\
\hline Slesinski et al. (2000a) & $\begin{array}{l}\text { Whey protein } \\
\text { concentrate }\end{array}$ & $\begin{array}{l}\text { Decreased pink color associated with both nitrite and nicotinamide in ground } \\
\text { turkey product }\end{array}$ \\
\hline Sammel and Claus (2003b) & $\begin{array}{l}\text { Whey protein } \\
\text { concentrate }\end{array}$ & Minimized nicotinamide-induced pinking in ground turkey \\
\hline
\end{tabular}


Table 9 - Influence of commonly used food-grade ingredients on pink color defect in fully cooked, uncured poultry products

\begin{tabular}{|c|c|c|}
\hline Reference & Ingredient & Observation \\
\hline Young and Lyon (1997) & $\begin{array}{l}\text { Sodium } \\
\text { tripolyphosphate }\end{array}$ & $\begin{array}{l}\text { Use of sodium tripolyphosphate in tumbling solutions decreased } \\
\text { internal cooked redness in chicken breast }\end{array}$ \\
\hline Schwarz et al. (1999) & EDTA & Pinking is decreased by EDTA in cooked whole muscle turkey \\
\hline Slesinski et al. (2000b) & EDTA & $\begin{array}{l}\text { EDTA eliminated pinking in turkey breast induced by nitrite, nitrate, } \\
\text { and nicotinamide }\end{array}$ \\
\hline Kieffer et al. (2000) & Citric acid & $\begin{array}{l}\text { Citric acid decreases pinking induced by nitrite and nicotinamide in } \\
\text { ground turkey }\end{array}$ \\
\hline Sammel and Claus (2003a) & Citric acid & $\begin{array}{l}\text { Effective to decrease pinking induced by nitrite and nicotinamide in } \\
\text { ground turkey rolls; but not effective in whole muscle turkey products }\end{array}$ \\
\hline Sammel and Claus (2003a) & Sodium citrate & $\begin{array}{l}\text { Effective to decrease pinking induced by nitrite and nicotinamide in } \\
\text { ground turkey rolls; but not effective in intact turkey breast }\end{array}$ \\
\hline Wills (2004) & $\begin{array}{l}\text { Sodium citrate and } \\
\text { citric acid blend }\end{array}$ & $\begin{array}{l}\text { Effective as a low ionic strength marinade to reduce pinking in fully } \\
\text { cooked chicken breasts }\end{array}$ \\
\hline Sammel et al. (2006) & Sodium citrate & $\begin{array}{l}\text { Sodium erythorbate inhibited the ability of sodium citrate to decrease } \\
\text { the pink color defect induced by nitrite and nicotinamide }\end{array}$ \\
\hline Sammel et al. (2007) & Calcium chloride & Pinking can be minimized by calcium chloride in ground turkey \\
\hline Sammel et al. (2007) & Annatto & Pinking in cooked ground turkey can be prevented by annatto \\
\hline Sammel and Claus (2007) & Calcium chloride & $\begin{array}{l}\text { Pinking can be minimized by calcium chloride in ground turkey, but } \\
\text { not in whole muscle turkey }\end{array}$ \\
\hline Sammel and Claus (2007) & Tricalcium phosphate & $\begin{array}{l}\text { Tricalcium phosphate, in combination with calcium chloride, was } \\
\text { effective to decrease pinking in ground turkey, but not in intact cooked } \\
\text { turkey breast }\end{array}$ \\
\hline Kim et al. (2015) & Citric acid & $\begin{array}{l}\text { Citric acid was effective as a dipping solution for chicken breast to } \\
\text { reduce pinking }\end{array}$ \\
\hline
\end{tabular}

